\title{
In vitro and in vivo biological performance of Mg-based bone implants
}

\section{Andreea Mariana Negrescu, Madalina-Georgiana Necula, Marieta Costache, Anisoara Cimpean ${ }^{\bowtie}$}

Department of Biochemistry and Molecular Biology, Faculty of Biology, Bucharest, Romania

${ }^{\circledR}$ Correspondence: anisoara.cimpean@bio.unibuc.ro

Received: 12 February 2020 / Revised: 22 May 2020 / Accepted: 26 June 2020 / Available online: 17 July 2020

\begin{abstract}
With the rapid advancement of medical technology, it is crucial that a considerable body of biomaterials are taken into consideration and tested for the purpose of bone implant fabrication. Over the last decades degradable metallic materials have attracted increasing interest in the field of hard tissue engineering due to their ability to degrade once they have fulfilled their function, without causing side effects that could potentially be harmful for the human body. In this context, Mg-based biomaterials gained special attention due to their bone-like mechanical properties, good biocompatibility and osteoconductive properties. However, their use in biomedical applications is limited due to their rapid corrosion in physiological environments. Therefore, it is important to reduce the degradation process of these biomaterials for safe biomedical applications. Two main strategies that could potentially lead to a lower corrosion rate are represented by alloying and surface treatment. This review provides a summary of the recent specialized literature concerning Mg-based biomaterials with a special focus on the recent in vitro and in vivo studies regarding $\mathrm{Mg}$-based bone implants.
\end{abstract}

Keywords: Magnesium, alloys, biodegradable bone implants, surface coatings, bone regeneration

\section{Introduction}

For a very long-time, alloys based on metals such as cobalt-chrome (Co-Cr), titanium (Ti) and stainless-steel, have been commonly used as essential biomaterials in the field of regenerative medicine (Antoniac, 2010) for repairing, improving and replacing injured or damaged bone tissue due to traumas or various pathological conditions such as osteoporosis and tumours (Antoniac et al., 2010). Their use in biomedical applications is justified by their excellent properties such as enhanced mechanical strength, good biocompatibility and satisfying life span. Additionally, these metals exhibit a low elastic modulus and negligible cytotoxicity (Dorozhkin et al., 2014). However, these classical metals have their limitations. Two major factors that contribute to the success of an implant are their biocompatibility and their matching mechanical properties (Wu et al., 2013; Sezer et al, 2018). When left in the human body for a long period of time they can become harmful to the surrounding tissue (Yang, 2011) due to the toxic particles and metallic ions released during the corrosion and wear processes (Puelo et al., 1995; Jacobs et al., 2003; Lhotka et al., 2003; Antoniac et al., 2010; Razavi et al., 2012).

Thus, the released elements may lead to a local chronic inflammatory process that can lower the biocompatibility and cause damage to the implantation sites (Poinern et al., 2012; Tian et al., 2015; Agarwal et al., 2016). More than that, the mismatch between the elastic modulus and tensile strength of the material and bone tissue leads to a phenomenon known as stress shielding which translates to a non-homogenous applied load transfer between the implant and the bone. Therefore, a reduction in the bone density can occur due to the fact that the bone tissue carries a lower load (Besiekierski et al., 2012; Li, 2015; Sezer et al., 2018). This may result in a decreased bone turnover (Kamrani et al., 2019) and a weak surrounding bone tissue. In addition, inert metallic implants require an invasive secondary procedure in order to remove the medical device after the remodelling and healing processes are complete (Razavi et al., 2012; Liu et al., 2018; Kamrani et al., 2019). This second procedure prolongs and increases the level of discomfort and pain, expanding the medical costs along with the risks the patient is submitted to (Liu et al., 2018; Kamrani et al., 2019). Bearing this in mind, the need of designing new biodegradable materials capable of overcoming the limitations displayed by the traditional metallic implants has become a necessity.

The concept of biodegradable materials has been introduced for the first time around 1960 by Kulkarni et al. (1966) and ever since a great interest in this direction 
has been observed, leading to the development of new biodegradable medical devices with clinical applications (Amini et al., 2011). Currently, the main materials approved and used as biodegradable materials are represented by resorbable polymers, metals and bioceramics (Tan et al., 2013; Neacsu et al., 2015; Li et al., 2017; Sezer et al., 2018; Liu et al., 2018; Kamrani et al., 2019) and even though, the medical market is primarily dominated, at the moment, by degradable polymers (Brar et al., 2009; Amini et al., 2011; Chen et al., 2014; Vojtech et al., 2014; Neacsu et al., 2015), certain biodegradable metals (Chen et al., 2014) have been taken into consideration due to their superiority in terms of strength, ductility and higher efficiency in comparison to resorbable polymers (Neacsu et al., 2015; $\mathrm{Li}$ et al., 2008; Zheng et al., 2014). A number of in vitro (Li et al., 2008; Pietak et al., 2008; Yun et al., 2009; Zhang et al., 2009; Gu et al., 2009; Gu et al., 2012; Li et al., 2012, Willbold et al., 2013; Chou et al., 2013; Homayun et al., 2014; Wua et al., 2014; Liu et al. 2014; Cipriano et al., 2015; Willbold et al., 2015) and preclinical studies (Gu et al., 2012; Willbold et al., 2013; Chou et al., 2013; Zheng et al., 2014), proved the efficiency of the magnesium-based materials in comparison to other biodegradable materials.

Magnesium $(\mathrm{Mg})$ is a light metal, with a density ranging from 1.74 g.cm ${ }^{-2}$ to 2 g.cm ${ }^{-2}$ (Kamrani et al., 2018) and an elastic modulus similar to that of natural bone (41-45 GPa) (Seal et al., 2009; Chen et al., 2014), therefore, minimizing the risk of a potential stress shielding phenomenon (Staiger et al., 2006; Xin et al., 2011). Also, $\mathrm{Mg}$ presents a highly reactive character (Mueller et al., 2010), property that allows $\mathrm{Mg}$ to naturally biodegrade in vivo in the presence of an aqueous media (Mueller et al., 2010; Dorozhkin et al., 2014). More than this, Mg-based materials showcase a good biocompatibility (Staiger et al., 2006; Peuster et al., 2006; Chen et al., 2014) and in vivo safety (Tian et al., 2015), being tolerated by the human body without causing any side effects whatsoever (Chen et al., 2014).

Even though in the last 15 years important achievements have been made in the field of degradable biomaterials, there are still some limitations that have not been overcome, hence the low use of pure Mg-based biomaterials in biomedical applications. One of these limitations is represented by the rapid corrosion in a physiological $\mathrm{pH}$ (7.4-7.6) and in a rich-chloride environment. The high corrosion rate of the material results in the production of hydrogen gas, a corrosion product that affects the mechanical integrity of the implant (Kannan et al., 2008; Chen et al., 2014). The released hydrogen gas forms "gas pockets" in the areas surrounding the implant, delaying the healing process and increasing the local pH (Poinern et al., 2012), likely causing cell apoptosis or necrosis (Sedelnikova et al., 2018). This can cause a local alkalinisation which affects the $\mathrm{pH}$-dependent physiological processes in the areas surrounding the implant (Antoniac et al., 2010). In order to slow down the rapid corrosion rate and improve their biocompatibility, researchers focused on developing feasible optimization procedures such as alloying and surface treatment (mainly coating techniques), in order to ease their transfer in clinical applications as biodegradable implants.

In this paper we review the recent progress in the field of degradable $\mathrm{Mg}$-based biomaterials, focusing on the recent in vitro and in vivo studies concerning $\mathrm{Mg}$-based bone implants.

\section{Short history of Mg-based biomaterials}

In 1808, Sir Humphrey Davy, discovers a new element that he names magnesium $(\mathrm{Mg})$, and shortly after its discovery, $\mathrm{Mg}$ is used in a variety of applications, starting from pyrotechnical and photographical applications to the field of medicine (Witte et al., 2010). Having as starting point the work of Michael Faraday, Robert Busen (1852) starts the commercial production of $\mathrm{Mg}$ (Witte et al., 2010) and shortly after that, Edward C. Huse (1878) uses Mg-based wires as blood vessels ligatures during 3 major surgical procedures (Walker et al., 2014). Huse is the first one to notice and mention the corrosive behaviour of the material, making the observation that its corrosion rate is lower in vivo and depends largely on the length of the wire that is used during the procedure (Witte et al., 2010). Following the success of Huse, a vast number of physicians started to use $\mathrm{Mg}$ and its alloys in various medical applications, but it is not until Payr, that $\mathrm{Mg}$ starts to be seen as a biodegradable material with other possible clinical applications (Witte et al., 2010). Payr starts his research in 1892, having as primarily focus the resorption of $\mathrm{Mg}$ (Witte et al., 2010) and by the year 1900 he comes with the hypothesis that Mg degrades due to the oxygen and water found in the tissues and minerals and carbon dioxide found in the blood (Witte et al., 2010). Also, he uses, with success, Mg-based medical devices in a series of procedures that involve suturing blood vessels and organs (Witte et al., 2010). In terms of orthopaedic applications, Albin Lambotte can be considered the pioneer even if his first attempts started off as a failure. In 1907 during a tibia fracture repair procedure, he used two different types of metals, pure $\mathrm{Mg}$ and steel, that led to a strong galvanic corrosion process and ultimately implant failure (Walker et al., 2014). Taking note of this observation he starts a series of animal experiments (Witte et al., 2010) that helped him reach the conclusion that $\mathrm{Mg}$-based materials start to corrode partially after 3 months and totally after 7 to 10 months (Witte et al., 2010; Walker et al., 2014). For a couple of years, Mg-based biomaterials have been the centre of attention and a large number of studies have been conducted with $\mathrm{Mg}$ as the primarily subject. Another Mg-based study took place in 1913. Ernest Hey Groves used for his experiment, Mg-based screws that he 
inserted in a rabbit, and the results obtained were not the ones he expected. He reported the formation of callus in the surrounding area of the implant coupled with the rapid corrosion of the implant before the tissues could regenerate properly (Walker et al., 2014). In 1917, Andrews used Mg clips and staples in a series of surgical procedures, but unlike the previous physicians he used $\mathrm{Mg}$ alloys alongside pure $\mathrm{Mg}$. His alloys contained elements like aluminium $(\mathrm{Al})$, zinc $(\mathrm{Zn})$ and cadmium (Cd), but they were somewhat brittle and hard in comparison to pure Mg (Pogorielov et al., 2018). Another physician who tried to alloy pure Mg was Seeling, by using elements like gold $(\mathrm{Au})$ and silver $(\mathrm{Ag})$ in order to increase the ductility of the material, but the results showed that the wires obtained from the newly developed Mg alloys had a low tensile strength (Pogorielov et al., 2018). Another study, but with positive results, was the one conducted by McBride in 1930, where he used a newly developed Mg-Al-Mn (manganese) alloy. He suggested that pure $\mathrm{Mg}$ is not as efficient as its alloys, due to its lower strength. In addition, in his paper he encourages the use of Mg-based biomaterials even if they can cause minor side effects. In 1944, Tsitrin and Troitskii used a Mg-Cd alloy for the treatment of different bone fractures. The study involved 34 patients and the results showed that only 9 procedures were considered to not be a success due to the infection (Pogorielov et al., 2018). Later on, in 1951, Stone and Lord used two types of $\mathrm{Mg}$ wires (pure $\mathrm{Mg}$ and $\mathrm{Mg}-\mathrm{Al}$ alloy) in a vascular procedure. They observed that the wire made of pure $\mathrm{Mg}$ was brittle but once $\mathrm{Al}$ was added (2\%) it became more pliable and therefore more suited for medical applications (Pogorielov et al., 2018).

However, even if a series of experiments showed positive results when it comes to the field of Mg-based biomaterials, $\mathrm{Mg}$ as a potential alternative for clinical applications has been considered too fragile to withstand the implantation process, so the research concerning $\mathrm{Mg}$ based implants has been dropped and overlooked until the end of the 90's when it started to gain popularity and ever since it holds the interest of researchers all over the world.

\section{Magnesium as a degradable biomaterial}

By definition, a biodegradable material is a material that once implanted in the human body it degrades gradually, without causing any harm due to its corrosion products, and disappears completely once the new tissue is formed. This is why, the composition of medical degradable devices should contain only essential metals found in the human body so that the products released during the corrosion process could be easily absorbed and metabolized or eliminated (Zheng et al., 2014). Recently, a particular interest for potentially use in clinic has been given to Mg-based biomaterials as a novel class of biodegradable bone implants due to their remarkable properties that puts them ahead of any other available biomaterial on the market. $\mathrm{Mg}$ is a light metal with a density of $1.74-2 \mathrm{~g} \cdot \mathrm{cm}^{-2}$, similar to natural bone tissue $\left(1.8-2.1 \mathrm{~g} \cdot \mathrm{cm}^{-2}\right)$, making it much lighter than any other type of material used currently in the field of regenerative medicine (Ti - $4.42 \mathrm{~g} \cdot \mathrm{cm}^{-2}$, stainless steel $-7.8 \mathrm{~g} \cdot \mathrm{cm}^{-2}$, PLLA-1 $\mathrm{g} \cdot \mathrm{cm}^{-2}$, hydroxyapatite (HA) - $3.156 \mathrm{~g} . \mathrm{cm}^{-2}$ ) (Tan et al., 2013). Also, Mg exhibits higher compression and traction forces compared to degradable polymers such as HA (Xin et al., 2011; Tan et al., 2013). An interesting feature of $\mathrm{Mg}$-based biomaterials is their Young modulus (Seal et al., 2009). Compared to Ti (110 $\mathrm{GPa}$ ) and steel (200 GPa), Mg has a Young modulus (41$45 \mathrm{GPa}$ ) similar to that of natural bone (Staiger et al., 2006; Seal et al., 2009; Xin et al., 2011; Tan et al., 2013); therefore, the risk of stress shielding is mitigated (Staiger et al., 2006; Tan et al., 2013; Liu et al., 2018). If not address properly, this biomedical phenomenon can result in serious clinical problems such as implant loosening, skeleton thickening and chronic inflammation (Salahshoor and Guo, 2012). Furthermore, Mg shows in vivo safety, being the fourth most abundant cation in the human body, with almost half of the amount found in bone (Okuma et al., 2001). Being brought into the body, in substantial amounts through diet (Liu et al., 2018) it showcases a variety of biological functions ( $\mathrm{Li}$ et al., 2017) such as key component for the ribosomal machinery that translates the genetic information encoded by mRNA into polypeptide and essential cofactor in almost all enzymatic systems involved in DNA processing (Hartwig et al., 2001; Li et al., 2017). Likewise, it is involved in processes such as biomineralization and bone tissue growth (Staiger et al., 2006; Gu et al., 2010; Fischer et al., 2013; Liu et al., 2018; Sedelnikova et al., 2018). Therefore, an increase in the concentration due to implant degradation will not pose as a threat to the living system (Tian et al., 2015). Zartner et al. (2007) and Heublein et al. (2003) reported positive results regarding the degradation process of $\mathrm{Mg}$ based medical devices and the minimal effects of the corrosion products released from them. Their results were supported by various in vivo studies on animals and postmortem studies on human subjects (Witte et al., 2005; Zartner et al., 2005; Witte et al., 2006; Witte et al., 2007). This characteristic could reduce some of the pathological problems associated with the implantation of traditionally metallic implants such as the release of inflammatory wear particles that could led to osteopaenia (Witte et al., 2005; Zheng et al., 2014; Zhao et al., 2016; Shuai et al., 2019). Furthermore, the development of newly degradable devices with favourable mechanical properties can significantly improve the life quality of patients from many points of view such as the elimination of the secondary removal surgery which will lead to lower costs, time needed and patient discomfort. It will also lower the risks caused by secondary effects associated with the medical procedure and the formation of scar tissue. In addition, it has been shown that $\mathrm{Mg}$ exhibits an antibacterial activity against bacteria such as 
Staphylococcus aureus, Escherichia coli and Pseudomonas aeruginosa (Robinson et al., 2010; Hsu et al., 2019).

From a chemical point of view, Mg exhibits a standard electrode potential of $-1.7 \mathrm{~V}$, making it very reactive (Haynes et al., 2013) and highly soluble in aqueous media (Mueller et al., 2010). The native $\mathrm{Mg}(\mathrm{OH})_{2}$ protective layer found on the surface of the implant is not strong enough to offer a prolonged protection against the corrosion process, especially in a chloride-rich environment (Song et al., 2003), due to the fact that the $\mathrm{Mg}(\mathrm{OH})_{2}$ layer is not compact, thus allowing the solution to infiltrate the film and trigger the corrosion process $(\mathrm{Li}$ et al., 2017). The chloride ions transform the native $\mathrm{Mg}(\mathrm{OH})_{2}$ layer in magnesium chloride $(\mathrm{MgCl})$, leaving the surface even more vulnerable to degradation due to the high solubility of $\mathrm{MgCl}$ (Staiger et al., 2006). The corrosion process is summarized in the following reactions:

$$
\begin{aligned}
& \mathrm{Mg}+2 \mathrm{Cl}^{-} \rightarrow \mathrm{MgCl}_{2} \\
& \mathrm{Mg}(\mathrm{OH})_{2}+2 \mathrm{Cl}^{-} \rightarrow \mathrm{MgCl}_{2}
\end{aligned}
$$

In the presence of an aqueous media, $\mathrm{Mg}$ goes through the following process:

$$
\mathrm{Mg}+2 \mathrm{H}_{2} \mathrm{O} \rightarrow \mathrm{Mg}^{2+}+2 \mathrm{OH}^{-}+\mathrm{H}_{2}
$$

This results in hydroxide $(\mathrm{OH})$ and hydrogen gas $\left(\mathrm{H}_{2}\right)$, a product that affects the implantation site in a negative way, by forming the so called "gas pockets", responsible for increasing the local $\mathrm{pH}$ of the environment, leading to the alkalization of the site surrounding the implant. The local alkalization affects most $\mathrm{pH}$-dependent physiological processes in the vicinity of the implantation site (Antoniac et al., 2010). More than that, this will lead to the loss of the mechanical integrity of the implant before the bone tissue has enough time to heal completely. Trying to predict the degradation behaviour of a $\mathrm{Mg}$ based biomaterial is a difficult task due to a number of factors such as environmental variation based on the region of implantion and time (Tang et al., 2006; Kamrani et al., 2019). Results have shown that time dependent corrosion is related to the nature of the corrosion layer found on the surface of the alloy (Witte et al., 2005; Wang et al., 2011). Also, the degradation rate of $\mathrm{Mg}$ is influenced by a series of factors (Fig. 1). When it comes to the corrosion process, there are two types of corrosion that could affect the Mg-based biomaterials, pit corrosion and galvanic corrosion. Pit corrosion is encountered in the case of single-phase materials (Walker et al., 2014) and consists in the rapid corrosion of small localized areas on the surface of the biomaterial that destroys the magnesium hydroxide protective layer (Poinern et al., 2012). The galvanic corrosion appears due to the presence of impurities in the $\mathrm{Mg}$ matrix or due to the presence of inter-metallic alloying elements (Poinern et al., 2012). Currently, the research is directed towards finding new strategies that could increase the corrosion resistance of the $\mathrm{Mg}$-based biomaterials, primarily through techniques like alloying and surface modifications. The following section will provide a summary of the strategies used so far to improve the performance of Mg-based biomaterials, focusing on the alloying process and surface modification that include surface coatings with different chemical compounds.

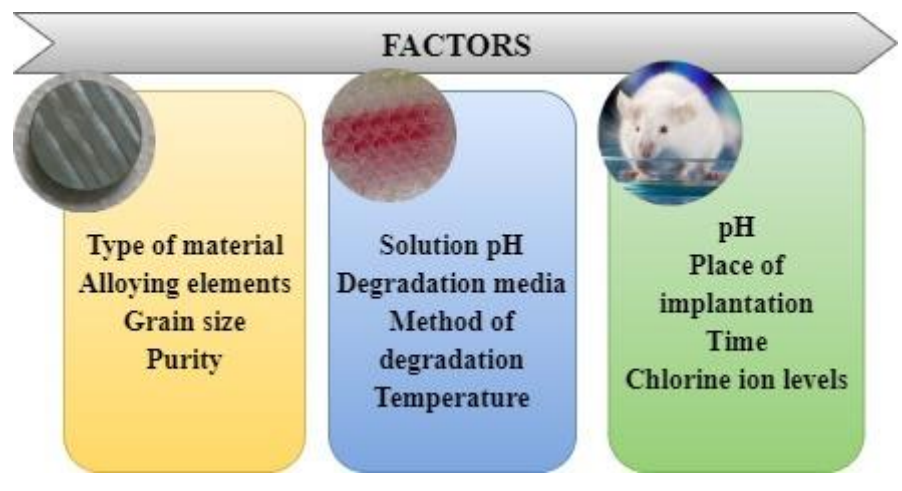

Fig.1. Factors that can influence the degradation rate of $\mathrm{Mg}$ based biomaterials

\section{Strategies to improve the biological performance of biodegradable Mg-based materials}

As mentioned before, Mg-based biomaterials have to meet a clear set of conditions before they could be considered potential candidates for bone implants such as: $i)$ exhibit a density and rigidity similar to those of the natural bone tissue; $i i)$ be able to fix itself around the bone; iii) show a low corrosion rate; iv) the corrosion products released during the degradation process should not be harmful for the human body (Neacsu et al., 2015).

However, their rapid degradation rate and harmful corrosion products, restricts their use as main biodegradable materials with biomedical applications (Staiger et al., 2006; Xu et al., 2011). This is the main reason why it is very important that the corrosion rate be kept under control, especially in the early stages of implantation. By improving the corrosion resistance, enough time will be given to the affected bone tissue to regenerate appropriately before the implant degradation can occur (Xu et al., 2012). In an effort to overcome the limitations imposed by the Mg-based biomaterials, various techniques were developed with the purpose of improving their performance. These techniques, as mentioned before, include $\mathrm{Mg}$ alloying and surface modifications, mainly surface coating techniques (Liu et al., 2007; Alvarez-Lopez et al., 2010; Wong et al., 2010; Walker et al., 2014).

\section{Alloying strategy}

One of the strategies used to improve the corrosion rate and mechanical properties of the Mg-based biomaterials 
is alloying (Kaesel et al., 2004; Antoniac et al., 2010; Bita et al., 2016). In general, pure $\mathrm{Mg}$ in the as-cast condition, exhibits a very low yielding strength (under 30 GPa) and a very rapid corrosion rate in physiological environments (Chen et al., 2014; Bita et al., 2016), thus explaining why $\mathrm{Mg}$-based biomaterials are usually found in the form of alloys. By adding in their composition, a specific combination of elements, mechanical properties such as strength, ductility, elongation and the corrosion resistance of the biomaterial can be greatly improved (Hort et al., 2010; Walker et al., 2014; Bita et al., 2016). This improvement occurs mainly due to the alteration of their microstructural characteristics such as grain size, which in comparison to pure $\mathrm{Mg}$ suffers a reduction (Sezer et al., 2018). Therefore, the secondary phase of the alloying system plays an important role (Li et al., 2008; Zhou et al., 2012; Li et al., 2017). The main elements used for alloying are $\mathrm{Al}, \mathrm{Ca}$, copper $(\mathrm{Cu})$, iron $(\mathrm{Fe}), \mathrm{Li}$, $\mathrm{Mn}, \mathrm{Sr}$, yttrium (Y), Zn and rare earth elements (REE) (Persaud-Sharma et al., 2012; Poinern et al., 2012; Chen et al., 2014; Farraro et al., 2014; Walker et al., 2014; Neacsu et al., 2015).

When it comes to biomedical applications, the composition of the alloying system is a very important factor that needs to be taken into consideration. Therefore, for an element to be considered suitable for alloying it must meet a series of requirements (Fig. 2).

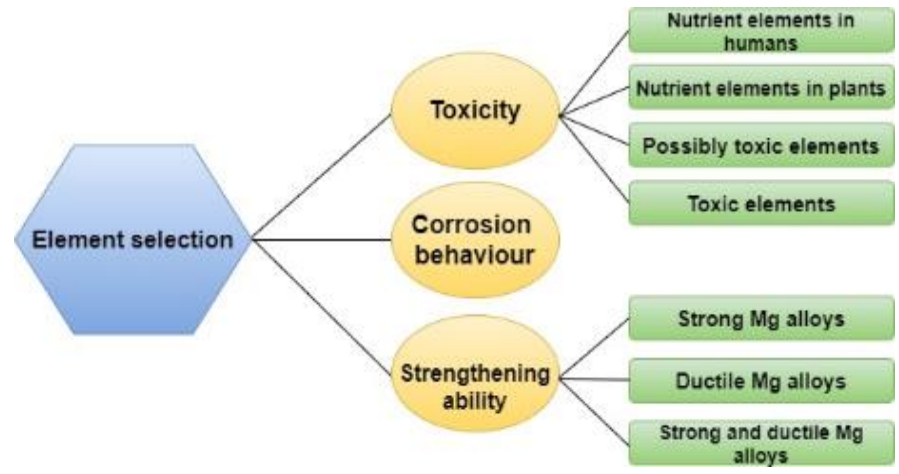

Fig. 2. Consideration of element selections for developing $\mathrm{Mg}$ based materials for bone implants.

First of all, the element should exhibit a reduced toxicity or be non-toxic, so that when the implant degradation occurs, the resulting products would not affect the human body. With this in mind, the alloying elements can be classified into four groups: $i$ ) nutrient elements found in the human body: $\mathrm{Ca}, \mathrm{Mn}, \mathrm{Zn}$, stannum ( $\mathrm{Sn})$, silicon $(\mathrm{Si})$; ii) nutrient elements found in animals and plants: $\mathrm{Al}$, bismuth (Bi), $\mathrm{Li}, \mathrm{Ag}, \mathrm{Sr}$, zirconium ( $\mathrm{Zr})$; iii) elements that can cause severe hepatotoxicity or other problems in the human body: $\mathrm{Al}$, vanadium $(\mathrm{V})$, chromium $(\mathrm{Cr})$, cobalt $(\mathrm{Co})$, nickel $(\mathrm{Ni}), \mathrm{Cu}$, lanthanum $(\mathrm{La})$, cerium $(\mathrm{Ce})$, praseodymium $(\mathrm{Pr}) ; i v)$ elements that are known to be toxic for the human body: beryllium (Be), barium (Ba), lead $(\mathrm{Pb}), \mathrm{Cd}$, thorium (Th) (Nakamura et al., 1997; $\mathrm{Gu}$ et al., 2009; Chen et al., 2010; Chen et al., 2014). Table 1 shows the toxicity limits for common elements used for alloying as synthesized from the paper by Kirkland et al. (2011).

Table 1. Toxicity levels for the elements used in alloying

\begin{tabular}{|c|c|}
\hline ELEMENT & DAILY ALLOWABLE DOSAGE (mg) \\
\hline $\mathbf{C a}$ & 1400 \\
\hline $\mathbf{A l}$ & 14 \\
\hline $\mathbf{Z n}$ & 15 \\
\hline $\mathbf{R E E}$ & 4.2 \\
\hline $\mathbf{F e}$ & 40 \\
\hline $\mathbf{N i}$ & 0.6 \\
\hline $\mathbf{S t}$ & 5 \\
\hline
\end{tabular}

At the moment, commercial Mg-based biomaterials contains in their composition elements such as $\mathrm{Al}, \mathrm{Zn}$ and REE, and even though they offer excellent mechanical properties and a greater corrosion resistance they are not suited for clinical applications due to their toxicity (Chen et al., 2014). For example, $\mathrm{Al}$ is a neurotoxic agent (Wills et al., 1983; Flaten et al., 1990; Flaten et al., 2001; Walker et al., 2014), especially if it is found in high concentrations like in the AZ91 and AM60 commercial alloys (Zhang et al., 2010; Chen et al., 2014). Zn, in high concentrations could lead to lung and breast cancer, while REE such as Ce, lutetium (Lu) and Pr are consider, in general, to be toxic for the human body causing severe hepatotoxicity (Yumiko et al., 1997; Antoniac et al., 2010; Poinern et al., 2012). Moreover, heavy metals exhibit a toxic potential for the body due to their ability to disrupt the normal molecular functions of the DNA, proteins and enzymes through the stable complexes that they form (Report of Environmental Health Impacts from Exposure to Metals, 2005; Poinern et al., 2012). Based on this, researchers have shifted their attentions towards the development of novel Mg-based alloys with low/no toxicity levels that contain in their composition only elements easily tolerated by the human body. Therefore, for biological applications binary alloys such as $\mathrm{Mg}-\mathrm{Ca}$ (Li et al., 2008); Mg-Zn (Zhang et al., 2010; Zhang et al., 2011); Mg-Si (Zhang et al., 2010); Mg-Gd (Yang et al., 2012); $\mathrm{Mg}$-Sr (Gu et al., 2012; Bornapour at el., 2013) and Mg-Y (Peng et al., 2010) have been designed.

The second consideration is the ability of the element to improve the durability and strength of the Mg-based biomaterials. Considering this, the alloying elements can be classified in four groups: $i$ ) elements that can increase simultaneous the strength and ductility of the material: $\mathrm{Al}, \mathrm{Zn}, \mathrm{Ag}, \mathrm{Ce}, \mathrm{Ni}, \mathrm{Cu}$, thorium (Th); ii) elements that can only increase the strength: $\mathrm{Sn}$, lead $(\mathrm{Pb}), \mathrm{Bi}$, antimony (Sb); iii) elements that can only increase the ductility: $\mathrm{Cd}, \mathrm{Th}, \mathrm{Li}$; iv) impurities: $\mathrm{Fe}, \mathrm{Ni}, \mathrm{Cu}, \mathrm{Co}$ (Polmear et al., 1999; Yang et al., 2008; Chen et al., 2014;). Impurities have the ability to reduce the efficiency of other elements found in the $\mathrm{Mg}$ matrix; therefore, their use should be well controlled or avoided (Persaud-Sharma et al., 2012). Their presence in the $\mathrm{Mg}$ matrix lowers the mechanical integrity of the implant, 
leading to its failure (Peng et al., 2010). Furthermore, these impurities can have a toxic effect on the human body (Chen et al., 2014), one of the examples being Ni. Studies have shown that $\mathrm{Ni}$ is harmful to cells, and only recently its toxicity on human lung epithelial A594 cells has been proved (Ahamed et al., 2011; Persaud-Sharma et al., 2014). An efficient method of controlling the level of impurities is the addition of certain elements that can reduce the negative effects caused by their presence (Chen et al., 2014). One example is Mn (Persaud-Sharma et al., 2012). Mn has the ability to reduce the negative effects caused by impurities such as $\mathrm{Fe}$ and lower the corrosive effects caused by $\mathrm{Ni}$.

Last but not least, the alloying elements must increase the corrosion resistance of the Mg-based biomaterials by reducing the internal galvanic corrosion. This can be achieved through the formation of an intermetallic phase with a similar potential to $\mathrm{Mg}(-2.37 \mathrm{~V})$ (Chen et al., 2014).

In an attempt to improve the performance of $\mathrm{Mg}$-based biodegradable implants, a series of elements such as $\mathrm{Ca}$, $\mathrm{Al}, \mathrm{Cu}, \mathrm{Mn}, \mathrm{Zn}$, gadolinium (Gd), Zr, Sr, have been used so far in the alloying process (Yang et al., 2008; PersaudSharma et al., 2012). Calcium is an essential element in the human body, involved in a large number of important cellular processes (Kim et al., 2008; Li et al., 2008; Walker et al., 2014). It is mainly used as an alloying element due to its ability to improve the mechanical properties of the alloy through the reduction of the grain size in comparison to pure $\mathrm{Mg}$ and a large number of studies (Drynda et al., 2010; Erdmann et al., 2010; Xin et al., 2010; Salahshoor et al., 2012) proved its ability to enhance the corrosion resistance of the alloy but only when it is added in small amounts $(0.5 \%)$.

Aluminium is a passivation element with a low density and the ability to improve the corrosion resistance of $\mathrm{Mg}$ alloys. Alloying systems containing Al possess a good corrosion resistance combined with a series of excellent mechanical properties (Walker et al., 2014). However, regardless of the improvements that $\mathrm{Al}$ brings to the alloys, it is still considered a highly toxic element for the human body and a large number of studies proved its involvement in a couple of affections and pathological conditions that affects the nervous system. Of those pathological conditions the most commonly known are dementia and Alzheimer's disease (Wills et al., 1983; Banks et al., 1989; Flaten et al., 1990; Flaten et al., 2001; Walker et al., 2014). In addition, in a laboratory setting, it was shown that $\mathrm{Al}$ can increase the expression of an estrogen-related gene in human breast cancer cells (Darbre et al., 2006).

Another element used for alloying is $\mathrm{Mn}$, an essential body nutrient that in large amounts can be toxic (Fell et al., 1996; Crossgrove et al., 2004; Walker et al., 2014) but when it is maintained in the acceptable limits it has the ability to improve the corrosion resistance of the material through the reduction of the negative effects caused by the presence of impurities found in the $\mathrm{Mg}$ matrix (Maker et al., 1993; Song et al., 1999; PersaudSharma et al., 2012; Walker et al., 2014). Also, it has the ability to enhance the alloy ductility (Pogorielov et al., 2017).

Another alloying element is $\mathrm{Zn}$. It is an essential trace mineral that can be found in the human body under normal conditions, playing an important role as a cofactor for a series of enzymes (Cotton et al., 1999; Brandt et al., 2009; Persaud-Sharma et al., 2012). When released from the implant as a corrosion product it does not pose as a threat for the body (Bothwell et al., 2003); however, in excessive amounts it can become toxic (Borovansky et al., 1989; Koh et al., 1994) having the potential to be corrosive if ingested. As an alloying element it has the ability to increase the strength of the material, being only second to Al from this point of view (Xu et al., 2008; Zhang et al., 2009; Walker et al., 2014) and, similar to $\mathrm{Mn}$, can reduce the effects caused by the presences of impurities in the Mg matrix (Song et al., 1999).

The REE category includes 15 elements that can be added to the alloying composition in order to improve the strength, ductility and corrosion resistance of the material (Witte et al., 2008; Peng et al., 2010). However, regardless of the fact that REE offers desired properties to $\mathrm{Mg}$-based alloys, their in vivo safety is debatable. A series of studies have shown their potentially toxic effects on the human body. The vast majority of REE exhibit anticarcinogenic and anticoagulant effects (Drynda et al., 2010), but certain elements such as Ce may cause severe hepatotoxicity. In addition, when found in excess, Y may be responsible for gene and DNA transcription factors modifications (Yang et al., 2006; Xin et al., 2011; Persaud-Sharma et al., 2012). Nevertheless, a number of studies have shown that, in low concentrations, REE do not exhibit cytotoxic effects. Likewise, combined with other alloying elements, they showcase positive effects on cell viability (Drynda et al., 2010; Feyerabend et al., 2010).

Other elements used for alloying are: $\mathrm{Zr}$, that is added due to its effective grain refining ability that helps improving the yielding strength of the material (Witte et al., 2008); Sr, which if it is added in the right amount can improve the corrosion resistance of the alloy (Niu et al., 2008; Li et al., 2013); Si, which has the ability to improve yield strength and ultimate tensile strength, being from this point of view the most efficient element (Gu et al., 2009). In addition, it has been shown that elements such as $\mathrm{Ca}, \mathrm{Sr}, \mathrm{Ag}$ and $\mathrm{Cu}$ have the ability to inhibit bacterial infection after surgery through the antimicrobial metallic ions released during the corrosion process (Li et al., 2008; Bornapour et al., 2013; Li et al., 2013; Tie et al., 2013; Zhao et al., 2014; Liu et al., 2016; Zhao et al., 2017; Liu et al., 2018). Table 2 denotes the common alloying elements and the improvements they bring to the materials once they are added to the pure $\mathrm{Mg}$ matrix. 
Table 2. Common elements found in the composition of Mg-based alloy

\begin{tabular}{|c|l|l|}
\hline ELEMENTS & $\begin{array}{c}\text { MECHANICAL ENHANCEMENTS GAINED AFTER } \\
\text { THE ALLOYING }\end{array}$ & \multicolumn{1}{|c|}{ REFERENCE } \\
\hline $\mathbf{A l}$ & $\begin{array}{l}\text { It is added to improve both the strength and the corrosion } \\
\text { resistance of the metal }\end{array}$ & $\begin{array}{l}\text { Bamberger et al., 2008; Wen et al., 2009; } \\
\text { Chen et al., 2014 }\end{array}$ \\
\hline $\mathbf{C a}$ & $\begin{array}{l}\text { Once added it has the ability to reduce the grain refining } \\
\text { size of the alloy; therefore, it improves the mechanical } \\
\text { properties of the alloy, offering a greater corrosion } \\
\text { resistance compared to the pure Mg }\end{array}$ & Drynda et al., 2010; Tan et al., 2013 \\
\hline $\mathbf{Z n}$ & $\begin{array}{l}\text { It is added in the alloy to improve the strength and reduces } \\
\text { the detrimental effects of impurities }\end{array}$ & $\begin{array}{l}\text { Song et al., 1999; Bch et al., 2003; Boehlert } \\
\text { et al., 2006; Xu et al., 2008; Zhang et al., } \\
\text { 2009; Tan et al., 2013; Walker et al., 2014 }\end{array}$ \\
\hline $\mathbf{R E E}$ & $\begin{array}{l}\text { Once added they increase the strength, corrosion } \\
\text { resistance, ductility and creep resistance of the alloy }\end{array}$ & $\begin{array}{l}\text { Dryna et al., 2008; Witte et al., 2008; } \\
\text { Feyerabend et al., 2010; Peng et al., 2010 }\end{array}$ \\
\hline $\mathbf{Z r}$ & $\begin{array}{l}\text { It is added to improve the strength and the corrosion } \\
\text { resistance }\end{array}$ & Witte et al., 2008; Brar et al., 2009 \\
\hline $\mathbf{M n}$ & $\begin{array}{l}\text { Once added it improves the corrosion resistance and } \\
\text { reduces the effects of certain impurities found in the alloy }\end{array}$ & $\begin{array}{l}\text { Makar et al., 1993; Song et al., 1999; } \\
\text { Sharma et al., 2012; Walker et al., 2014 }\end{array}$ \\
\hline $\mathbf{S t}$ & $\begin{array}{l}\text { It is added to improve the corrosion resistance by refining } \\
\text { the grain size of the alloy }\end{array}$ & Niu et al., 2008; Li et al., 2013 \\
\hline
\end{tabular}

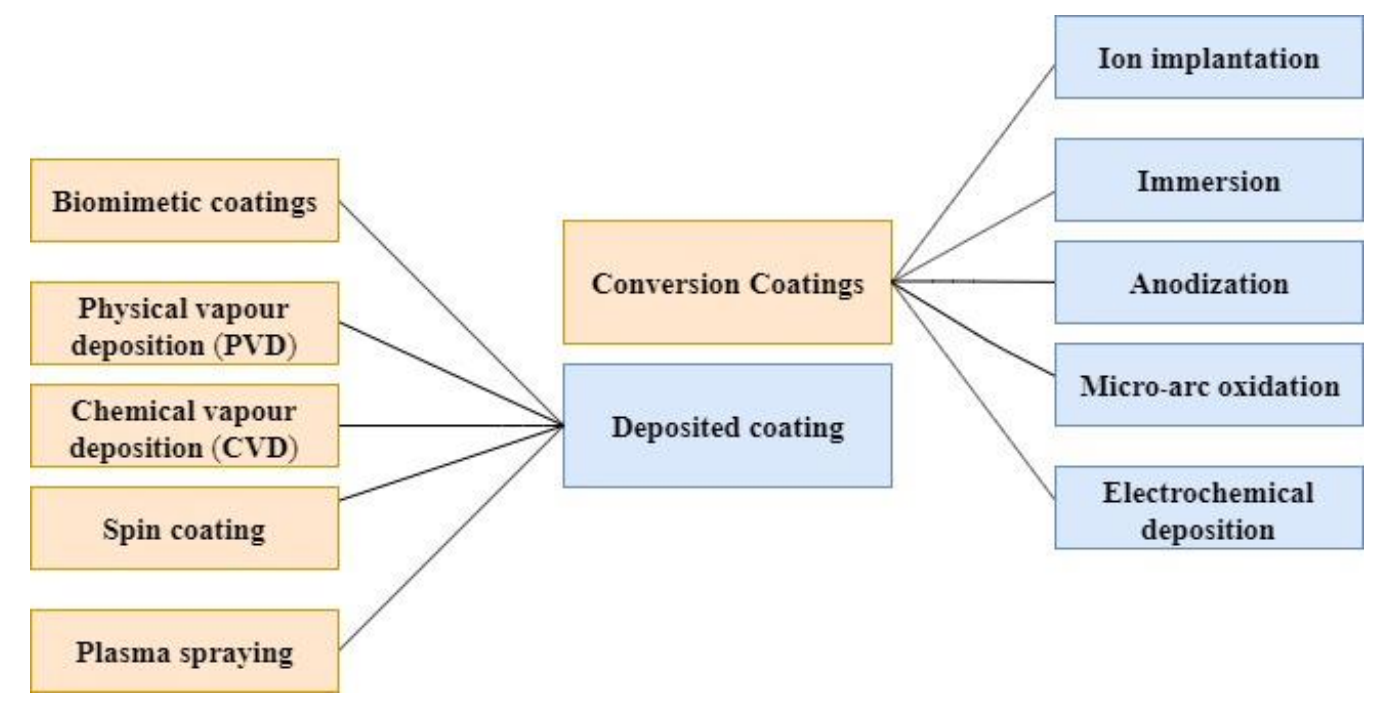

Fig. 3. Overview of conversion and deposition coatings procedures

\section{Surface treatment strategy}

Besides alloying, other strategies can be used in order to improve the performance of $\mathrm{Mg}$-based biomaterials and bring them closer to the requirements needed for their use as bone implants. One of these approaches is represented by surface treatment or coating, which similar to alloying helps lowering the corrosion rate of various $\mathrm{Mg}$ alloys to a desired rate (Hornberger et al., 2012; Li et al., 2013; Walker et al., 2014). A favourable surface coating has to possess the same requirements as the $\mathrm{Mg}$ alloy itself of being biocompatible and fully degradable, while leaving no harmful traces in the human body (Kirkland et al., 2011). To be suited for biomedical applications, the coatings should possess other functions beside protections, such as the ability to enhance the biocompatibility, osseointegration, bioactivity, local drug delivery ability and the mechanical stability of the implantable device. Moreover, it should reduce the production of hydrogen gas released during the degradation process of the $\mathrm{Mg}$ alloy (Neacsu et al., 2015). It is also important to take into account the toxicity of the coating layer, which is why the materials used should not show any signs of cytotoxicity.

Moreover, the corrosion products released from the coating have to be non-toxic and easily absorbed by the surrounding tissue (Walker et al., 2014). Wang et al. (2012), classified the surface treatments in two categories, i.e. chemical (conversion) and physical (deposition) (Fig. 3). The chemical treatment includes techniques such as ion implantation, fluoride treatment, anodization, acid etching and alkaline treatment. All of these methods are based on the ability of removing the 
native magnesium hydroxide layer found on the surface of the material (Wang et al., 2012; Walker et al., 2014) that offers protection against the degradation process, just not as efficient as it should have when put into a rich-chloride environment. On the other hand, the physical treatment consists in the deposition of an organic, inorganic or metallic coating on the surface of the material, thus leading to the formation of a protective barrier between the corrosive physiological environment and the biodegradable material (Gray et al., 2002; Yang et al., 2011; Hornberger et al., 2012; Walker et al., 2014; Yin et al., 2020). In some cases, a combination of the two methods can be used, which consists in the initial chemical treatment of the surface in order to improve the adhesion of the coating that has been obtain through a physical treatment (Wang et al., 2012).

The anti-corrosive coatings on Mg-based materials designed for biomedical applications having been studied and described in various articles so far include: magnesium fluoride $\left(\mathrm{MgF}_{2}\right)$, that helps decreasing the in vivo corrosion rate and temporarily delays the release of elements from the alloying system (Yang et al., 2011), calcium phosphate $\left(\mathrm{Ca}_{3}\left(\mathrm{PO}_{4}\right)_{2}, \mathrm{CaP}\right)$ that helps promoting the osteogenesis and osseointegration and suppresses the release of the corrosion products (Kokubo et al., 2006), fluorinated hydroxyapatite (FHA) that promotes the mineralization and crystallization of $\mathrm{CaP}$ during the formation of the new bone tissue through the fluorinated ions (Qu et al., 2006) and bioactive glass (Rau et al., 2016) (Fig. 4).

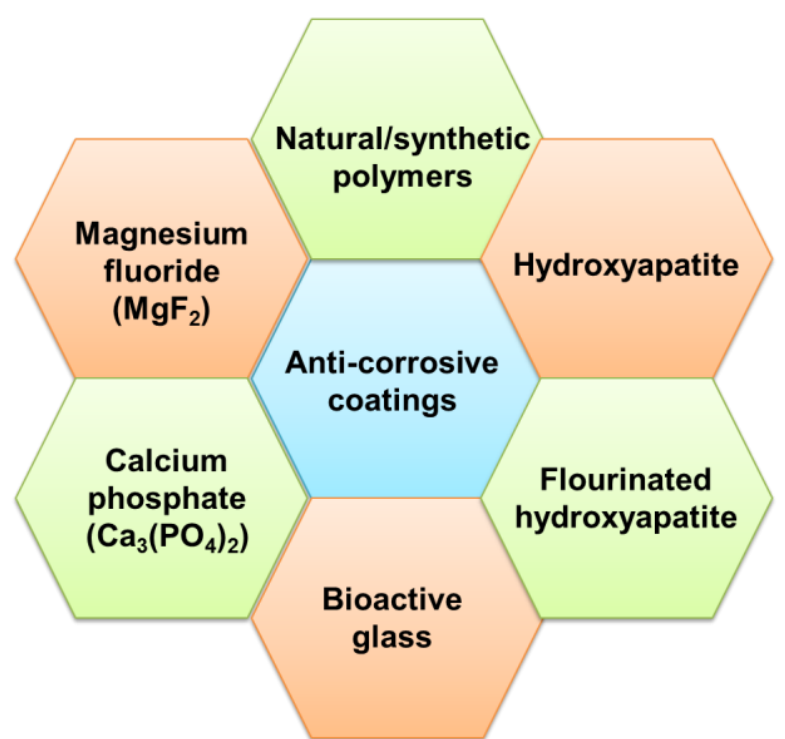

Fig. 4. Types of coatings used for biomedical application

At the moment, the most commonly used surface coatings are the ones based on polymers and $\mathrm{CaP}$ (Hornberger et al., 2012; Liao et al., 2013; Chen et al., 2014; Gaur et al., 2014; Li et al., 2014; Neacsu et al., 2015) due to their increased biocompatibility and ability to enhance the corrosion resistance of the Mg-based materials.

\section{Polymer based-coatings}

Among various biodegradable materials used as an anticorrosion barrier, polymers, natural or synthetic, are the primarily materials used for tissue engineering applications and bone implants. The appropriate selection of the polymer-based coating is a very important step in the development process since it can influence the biocompatibility of the base biomaterial, and it is generally made based on the property that needs to be improved. Moreover, the interface between the body environment and the surface of the implant is critical in eliciting an appropriate immune response. That is why selecting the biomaterial for the coating can be as important as selecting the alloying system. The protective ability of the polymer-based coating is mainly influenced by the molecular weight and polymer concentration, which in turn influences the polymer's viscosity. In addition, the quality and thickness of the coating depends largely on the viscosity of the polymer (Chen et al., 2014).

Polymer-based coatings do not only possess the ability to enhance the corrosion resistance of the medical devices but they also improve the biocompatibility of the said devices. Furthermore, they can improve cellular processes such as adhesion and proliferation (Wong et al., 2010; Xu et al., 2012). In the context of biomedical applications, the polymer coating must be flexible to withstand the natural movement of the implant and maintain its mechanical integrity over a longer period of time allowing enough time for the healing process to take place. The biodegradable polymers that received the Food and Drug Administration (FDA) approval for their use in human clinical trials includes poly (L-lactic acid) (PLLA); poly (glycolic acid) (PGA) and poly ( $\varepsilon-$ caprolactone) (PCL) (Mano et al., 2004; Neacsu et al., 2015). Starting from these biodegradable polymers, the polymer-based coatings that are being used in clinical applications are represented by: $i$ ) PLLA (Alabbasi et al., 2012; Hornberger et al., 2012; Xu et al., 2012; Xu et al., 2012); ii) PCL (Wong et al., 2010; Xu et al., 2012; Xu et al., 2012); iii) poly(lactic-co-glycolic acid) (PLGA). Methods like spin coating, dip coating and spraying are used to apply the coatings on the surface of the Mg-based biomaterials (Chen et al., 2014).

\section{Calcium Phosphate-based coatings}

Another biodegradable material used as a coating is $\mathrm{CaP}$, which helps promoting the direct attachment of the implant to the surrounding tissue and prevents the releasing of the corrosion products into the human body (Kokubo et al., 2006; Razavi et al., 2012). Moreover, in comparison with the other coatings, $\mathrm{CaP}$ leads to the formation of a HA layer, similar to the mineralization phase of the natural bone (Hornberger et al., 2012). By coating $\mathrm{Mg}$-based materials with plain $\mathrm{CaP}(\mathrm{Xu}$ et al., 2009; Yanovska et al., 2012; Rojaee et al., 2013; 
Dorozhkin et al., 2014; Surmenev et al., 2014; Neacsu et al., 2015) or with biocomposites based on CaP (Du et al., 2011; Zhang et al., 2012; Johnson et al., 2013; Wang et al., 2013; Zhang et al., 2013; Qiu et al., 2014) the corrosion rate of the material will be considerable decreased. Furthermore, when is applied to the material surface under a thin layer it can improve important cellular processes like adhesion, proliferation and differentiation, thus, playing an important role in tissue regeneration (Surmenev et al., 2014).

Hydroxyapatite, the main inorganic constituent of the natural bone, is widely used as a coating for Mg-based biomaterials. It results at the end of the mineralization process and it is used in clinic as a biomedical material either as a protective layer or powder due to its excellent bioactivity and biocompatibility (Wang et al., 2013; Antoniac et al., 2020). It possesses an increased osteoconductive potential, mainly due to its structural and chemical similarity to the natural bone (Erbe et al., 2001; Ghosh et al., 2008; Dai et al., 2011; Wang et al., 2013). Additionally, a series of studies demonstrated its ability to act as a carrier for a number of osteoconductive growth factors and some osteogenic cell populations (Noshi et al., 2000). Also, in a physiological environment, it has the lowest solubility of all CaP coatings (Desai et al., 2008). All of the above properties have transformed HA coatings into favourable candidates for clinical applications. In recent years, HA coatings have been replaced with fluorinate hydroxyapatite (FHA) due to its better protein adsorption ability, lower rate of dissolution and good biocompatibility. In addition, the fluoride ions promote the mineralization and crystallization of $\mathrm{CaP}$ during the formation process of the bone $(\mathrm{Qu}$ et al., 2006). Although the number of studies involving HA coatings deposited on Ti-based materials is extensive, in the field of Mg-based materials, studies are still in the initial phase.

Tricalcium phosphate $\left(\mathrm{Ca}_{3}\left(\mathrm{PO}_{4}\right)_{2} ; \mathrm{TCP}\right)$ is a resorbable bioactive ceramic material composed of two phases, $\alpha$ and $\beta$-TCP (Tan et al., 2013), with the $\beta$-TCP phase predominant at lower temperatures of 900-1100 degrees Celsius (Driessen et al., 1982; Yubao et al., 1997) and the alpha phase predominating at much higher temperatures, up to $1250{ }^{0} \mathrm{C}$ (Driessen et al., 1982; TenHuisen et al., 1998). Between the two phases, only $\beta$-TCP is used in the medical field in bone regeneration applications. TCP is an osteoconductive material (Cai et al., 2009; Chappard et al., 2010; Rokn et al., 2012) with a faster biodegradation rate than the rest of the ceramics (e.g., HA). The small particle size and the interconnected sponge like microporosity gives TCP the ability to improve the material's osteoconductivity and to enhance the remodelling of bone tissue by promoting the resorption process (Erbe et al., 2001; Hing et al., 2007; Ghosh et al., 2008; Nandi et al., 2008; Tan et al., 2013).

\section{Bioactive glass-based coatings}

Discovered by Hench et al. (1971), the bioactive glass showed various applications, including in the field of bone regenerative medicine (Vogel et al., 2001; Dorea et al., 2005). Bioactive glass has the ability to fix itself to the surrounding bone tissue in the absence of a fibrous connective tissue interface (Duskova et al., 2002; Bita et al., 2016), possessing both osteoconductive and osteoinductive proprieties (Hench et al., 1998; Hench et al., 2006; Jones et al., 2007). When it first came out, its composition contained $45 \mathrm{wt} \% \mathrm{SiO}_{2}, 24.5 \mathrm{wt} \% \mathrm{CaO}, 24.5$ wt $\% \mathrm{Na}_{2} \mathrm{O}$ and 6 wt $\% \mathrm{P}_{2} \mathrm{O}_{5}$ (Hench et al., 1991), but in time the composition suffered minor changes such as removal of sodium (Na) and the addition of other elements like $\mathrm{Mg}$ (Vitale-Brovarone et al., 2007; VitaleBrovarone et al., 2008), Ag (Blaker et al., 2004; Bellantone et al., 2007; Balamurugan et al., 2008; Delben et al., 2009), potassium (K) (Cannillo et al., 2009), Zn (Aina et al., 2009; Haimi et al., 2009), Fe (His et al., 2007). Studies showed that high contents of sodium oxide $\left(\mathrm{Na}_{2} \mathrm{O}\right)$ and calcium oxide $(\mathrm{CaO})$ in the composition of the bioactive glass led to a highly reactive surface when put in a physiological environment (Hench et al., 1991). By replacing silicon oxide $\left(\mathrm{SiO}_{2}\right)$ with $15 \%$ diboron dioxide $\left(\mathrm{B}_{2} \mathrm{O}_{2}\right)$ and $\mathrm{CaO}$ with $12 \%$ calcium fluoride $\left(\mathrm{CaF}_{2}\right)$ no modifications in the surface's bioactivity could be observed (Gross et al., 2004) but when $12 \%$ aluminium oxide $\left(\mathrm{Al}_{2} \mathrm{O}_{3}\right)$ was added, issues with the bioactive glass' ability to fix itself to the surrounding bone was observed.

\section{In vitro studies of currently developed Mg-} based biomaterials

Despite the great potential of $\mathrm{Mg}$-based biodegradable materials for clinical applications, their rapid degradation rate limits their use as implantable devices. An ideal biodegradable and bioresorbable implant should possess a favourable mechanical strength and a low degradation rate, while being able to promote new bone formation and tissue healing around the implant site (Neacsu et al., 2015). Therefore, different new Mg-based biomaterials were developed and their in vitro response was investigated in order to predict their in vivo behaviour and their potential as biodegradable implants for clinical applications.

\section{Mg-Alloys}

Mg-Ca alloys. Calcium (Ca) is one of the major components of the bone tissue, being essential in various cellular processes, thus indispensable from the human body. In terms of alloying, Ca possesses a low density and a solubility limit of $1.34 \mathrm{wt} \%$, properties that gives the binary $\mathrm{Mg}-\mathrm{Ca}$ alloy system, bone like properties ( $\mathrm{Li}$ et al., 2008), thereby making it a perfect candidate for alloying. A large body of in vitro studies evaluated the effect of the amount of $\mathrm{Ca}$ on the mechanical properties 
of a Mg-Ca alloy system. Drynda et al. (2010) evaluated the effect of $\mathrm{Ca}$ content within a $\mathrm{Mg}-\mathrm{Ca}$ alloy, regarding strength and ductility, and the results show that high $\mathrm{Ca}$ contents led to a higher strength and lower ductility. Additionally, Tan et al. (2013) observed that by increasing the secondary phase of the binary alloy, an enhancement in the corrosion resistance could be acquired. Similar results were reported by Harandi et al. (2013), in their paper where it was investigated the effect of $\mathrm{Ca}$ addition on the microstructure and corrosion behaviour of five different $\mathrm{Mg}$-xCa alloys. Their results showed that by increasing the $\mathrm{Ca}$ content an increase in the secondary phase of the binary alloy could be observed. Furthermore, the in vitro corrosion evaluation showed that the addition of $\mathrm{Ca}$ led to a shift in the $\mathrm{pH}$ value of the fluid to a higher level similar to those found in pure $\mathrm{Mg}$, which led to the formation and growth of bone like apatite. However, increasing the $\mathrm{Ca}$ content led to a lower corrosion resistance, thus indicating that minimum amounts of $\mathrm{Ca}$ are the most beneficial in terms of clinical applications. Furthermore, Rad et al. (2012) reported that by adding higher amounts of $\mathrm{Ca}$ in the microstructure of a $\mathrm{Mg}-\mathrm{Ca}$ binary alloy, a significantly reduction of the grain and cell size could be observed, leading to an alloy unsuitable for clinical applications with a low ductility and corrosion resistance. In order to improve its performance, a series of elements can be added into the composition of the binary $\mathrm{Mg}$-Ca alloy, one example being Zn. Du et al. (2011) added Zn into the composition of a $\mathrm{Mg}-3 \mathrm{Ca}$ alloy, and the results obtained showed an improvement in strength and ductility of the system. Li et al. (2008) investigated the biological performance of a binary $\mathrm{Mg}-\mathrm{Ca}$ alloy with various $\mathrm{Ca}$ contents (1-3 wt\%) and different fabrication conditions, the results revealed that the binary alloy did not induce any cytotoxic effect on the L-929 cells. Moreover, in vitro corrosion tests showed that a mixture of $\mathrm{Mg}(\mathrm{OH})_{2}$ and HA has been formed in time on the surface of the binary alloy. These results were supported by data obtained during in vivo studies ( $\mathrm{Li}$ et al., 2008). Makkar et al. (2018) evaluated the in vitro performance of binary $\mathrm{Mg}$-xCa alloys $(0.5 \mathrm{wt} \%$ and $5.0 \mathrm{wt} \%)$ for use as biodegradable biomaterials within bone. The results showed a better behaviour for the $\mathrm{Mg}-0.5 \mathrm{Ca}$ alloy in comparison to the $\mathrm{Mg}-5.0 \mathrm{Ca}$ alloy, both in terms of biocompatibility and corrosion resistance, suggesting that the $\mathrm{Mg}-0.5 \mathrm{Ca}$ alloy could be used as a biodegradable base material for clinical applications.

Mg-Al alloys. Aluminium (Al) is one of the most commonly used alloying element due to its ability to improve both the corrosion resistance and the strength of the alloy. It possesses a maximum solubility of $12.7 \mathrm{wt} \%$ in $\mathrm{Mg}$ (Chen et al., 2014) and when dissolved in the $\mathrm{Mg}$ matrix it results in the formations of two phases, $\alpha(\mathrm{Mg})$ and $\gamma\left(\mathrm{Mg}_{17} \mathrm{Al}_{12}\right)$ (Bamberger, 2008). Chen et al. (2014) reported that by adding $\mathrm{Al}$ in the $\mathrm{Mg}$ matrix, an improvement in strength and corrosion resistance of the alloy could be observed. Likewise, Wen et al. (2009) studied the effect of $\mathrm{Al}$ content within $\mathrm{Mg}-\mathrm{Al}$ alloys and noticed that by increasing the amount of $\mathrm{Al}$, the corrosion resistance and strength of the alloy can be further enhanced. However, Zheng et al. (2014) showed that by exceeding the $\mathrm{Al}$ content by $6 \mathrm{wt} \%$, a significant decrease in the alloy strength occurs. Similar results were obtained by Xin et al. (2011). In their study a lower corrosion resistance was reported due to the increased presence of the $\mathrm{Mg}_{17} \mathrm{Al}_{12}$ phase that promoted the galvanic corrosion. The most common $\mathrm{Mg}-\mathrm{Al}$ alloys commercially found on the market and used in biomedical applications are represented by AZ31 (Witte et al., 2005; Lu et al., 2007; Gray-Munro et al., 2009; Wen et al., 2009; Gu et al., 2011), AZ61 (Wen et al., 2009), AZ91 (Witte et al., 2005; Lu et al., 2007; Kannan et al., 2008; Wen et al., 2009;) and AM60 (Lu et al., 2007).

Mg-Zn alloys. Exhibiting a solubility limit of $6.1 \mathrm{wt} \%$ in $\mathrm{Mg}$ and two main phases, $\alpha-\mathrm{Mg}$ and $\gamma-\mathrm{MgZn}$ (Zhang et al., 2011), $\mathrm{Zn}$ is the second most commonly used metal for alloying (Persaud-Sharma et al., 2012; Walker et al., 2014). By adding $\mathrm{Zn}$ within the alloying system, an increase in strength (Bch et al., 2003; Boehlert et al., 2006; Xu et al., 2008; Zhang et al., 2009; Tan et al., 2013; Walker et al., 2014) and the corrosion resistance of the alloy could be obtained. One possible explanation could be the reduction of the harmful effects of the impurities found in the $\mathrm{Mg}$-matrix, such as $\mathrm{Fe}, \mathrm{Cu}$ and $\mathrm{Ni}$ (Song et al., 1999). Cai et al. (2012) developed a binary $\mathrm{Mg}-\mathrm{Zn}$ alloy with a $5 \mathrm{wt} \% \mathrm{Zn}$ content and the results showcased a secondary phase strengthening and grain boundary that led to an improvement in the mechanical properties and corrosion resistance of the alloy. In addition, $\mathrm{Zn}$ can reduce the production of hydrogen gas released during the corrosion process. Zberg et al. (2009) investigated the effect of $\mathrm{Zn}$ content within $\mathrm{Mg}$ alloys and noticed that alloying systems containing smaller amounts of $\mathrm{Zn}$ in their composition led to a higher release of hydrogen gas, while alloys with a higher percentage of $\mathrm{Zn}$ released no significant levels of hydrogen during the corrosion process. In terms of cytotoxicity, $\mathrm{Zn}$ can only become toxic at very high concentrations (Borovansky et al., 1989; Koh et al., 1994). Zhang et al. (2010) evaluated a patented $\mathrm{Mg}-6 \mathrm{Zn}$ alloy in terms of biocompatibility and the results obtained showed no cytotoxic effects on the cells whatsoever. Chen et al. (2011) tested the in vitro biocompatibility of a $\mathrm{Mg}-\mathrm{Zn}$ alloy in terms of cell attachment, mineralization and osteogenic-specific mRNA expression. The results obtained revealed better cell attachment and improved mineralization ability for the cells cultured on the binary alloy in comparison to the PLLA control. However, in terms of corrosion, the alloy corroded faster than the control. Cipriano et al. (2015) evaluated the behaviour of bone marrow derived mesenchymal stem cells (BMSCs) at the interface with four biodegradable $\mathrm{Mg}-\mathrm{xZn}-0.5 \mathrm{Ca}$ alloys. Their results suggested that minimal amounts of $\mathrm{Zn}$ did not improve 
the corrosion resistance of the system, while in terms of cytotoxicity no significant differences were observed in comparison to the control.

Mg-Zr alloys. Zirconium ( $\mathrm{Zr})$ is generally added within the alloy as a grain refiner (Witte et al., 2008; Peng et al., 2010; Walker et al., 2014) in order to improve the corrosion behaviour and strength (Babkin et al., 2004; Huan et al., 2010). Zhang et al. (2012) showed that by adding $1 \mathrm{wt} \% \mathrm{Zr}$ within the alloying system, a great improvement in strength and ductility of the alloy could be observed, along with a $50 \%$ reduction in the corrosion rate compared to pure Mg. Similar to other elements, such as $\mathrm{Mn}$, it has the ability to lower the corrosion rate of the alloy by reducing the harmful effects of impurities. Huan et al. (2010) revealed that by maintaining the $\mathrm{Zr}$ content under a $0.48 \mathrm{wt} \%$ limit, a reduction in the corrosion rate of the alloy could be observed, but once the threshold is surpassed the precipitation of the $\mathrm{Zr}-\mathrm{Fe}$ particles is no longer possible. Additionally, $\mathrm{Zr}$ can be used in combination with other alloying elements, with different outcomes. When put together with $\mathrm{Al}$ and $\mathrm{Mn}$ it led to the formation of a stable compound that cancelled its ability as a grain refiner. In addition, a series of studies have revealed that $\mathrm{Zr}$ possesses low cytotoxicity, good biocompatibility and enhanced in vivo osseocompatibility.

Mg-REE alloys. The REE category includes 15 elements and the most frequently studied Mg-REE alloys to date are represented by Mg-Gd (Nakamura et al., 1997), Mg$\mathrm{Ce}, \mathrm{Mg}-\mathrm{Nd}$, Mg-La and Mg-Y (Tan et al., 2013). Usually, REE are added within the alloying system with the purpose of improving the mechanical properties of the Mg-based biomaterials, since their contribution towards improving the corrosion rate of the alloy is not beneficial due to their either anodic or cathodic character (Song et al., 2019). Birbilis et al. (2009) showed that REE exhibiting a low solid solubility in the $\mathrm{Mg}$ matrix induced the formation of the secondary phase that enhances the corrosion process of $\mathrm{Mg}$ alloys. On the contrary, Hort et al. (2010) and Peng et al. (2010) reported that the addition of highly soluble RRE in the $\mathrm{Mg}$ matrix, led to the formation of an intermetallic free $\mathrm{Mg}$ alloy that demonstrated a higher corrosion rate when compared to pure $\mathrm{Mg}$. Elements like $\mathrm{Gd}$ and $\mathrm{Nd}$ attracted a growing interest in the recent years due to their ability to improve the corrosion rate of the alloy. Seitz et al. (2011) investigated the mechanical and corrosive features of a Mg- $2 \mathrm{Nd}$ alloy and the results showed positive results in terms of cell viability/proliferation and corrosion rate, suggesting that the alloying system can be a potential candidate for biomedical applications. Bian et al. (2018) evaluated the biological performance of a $\mathrm{Mg}-\mathrm{Zn}-\mathrm{Gd}$ alloy and the in vitro results revealed a lower degradation rate. In addition, this alloy did not show any cytotoxicity on the MG63 osteoblasts, vascular smooth muscle cells (VSMC) and L292 fibroblasts. Zhang et al. (2012a) observed that after extrusion, a $\mathrm{Mg}-3 \mathrm{Nd}-0.22 \mathrm{Zn}-0.4 \mathrm{Zr}$ alloy exhibits an improvement in strength and ductility due to the dynamic precipitation and grain refinement of the $\mathrm{Mg}_{12} \mathrm{Nd}$ phase. Likewise, Zhang et al. (2012b) reported that after extrusion, a $\mathrm{Mg}-11.3 \mathrm{Gd}-2.5 \mathrm{Zn}-0.7 \mathrm{Zr}$ alloy showed a favourable corrosion resistance and excellent mechanical properties due to the formation of the intermetallic $\mathrm{Mg}_{5} \mathrm{Gd}$ phase. However, due to its rich content in $\mathrm{Gd}$ it also possessed a cytotoxic potential.

In Fig. 5 are indicated the main properties exhibited by the most common $\mathrm{Mg}$ alloys being used in various medical applications.

\section{Surface coatings}

Various in vitro studies focused on the surface modification methods and different degrees of improvements in the corrosion rates of the Mg-based biomaterials have been reported. Table 3 summarises the most relevant studies regarding different types of coatings for Mg-based biodegradable materials.

Polymer-based coatings. A popular topic in biomaterials research is represented by the evaluation of polymer coatings deposited on Mg-based biomaterials, with PLLA, PCL and PLGA coatings being the most common ones. Abdal-hay et al. (2013a) developed a hydroxyapatite/poly( $\varepsilon$-caprolactone (nHAp/PCL) coating on a $\mathrm{Mg}$ alloy AM50 via dip coating and the results showed that both the uncoated and coated samples presented a good corrosion resistance in simulated body fluid (SBF) but on long term it was the coated alloy that exhibited a superior corrosion resistance compared to the uncoated and single PCL coated samples. In addition, the coated alloy displayed an improved bioactivity due to the presence of HA particles (HAp) that possess the ability to enhance cell adhesion and proliferation on the surface of the alloy. In another study, Abdal-hay et al. (2013b) deposited a HAp-PLA coating on an AZ31B substrate with the purpose of attaining a better control over the degradation rate and bone formation. By covering the surface of the alloy with a thinner layer of coating, an improvement in the corrosion resistance was observed due to the presence of the precipitated apatite formed by the HAp. Furthermore, the cytotoxicity evaluation showed no harmful effects on the cell growth. Li et al. (2010) deposited a PLGA coating on a Mg-6Zn alloy and noticed that in comparison to the plain alloy the corrosion resistance of the coated alloy was improved significantly. Additionally, the presence of the coating led to an enhancement in the cell adhesion process. Wong et al. (2010) deposited on a commercial AZ91 substrate a newly tailored biodegradable polymer-based porous membrane (PCL/dichloromethane) and the results showed a reduction in the corrosion rate. Neacsu et al. (2017) evaluated the in vitro biocompatibility of a newly cellulose acetate $(\mathrm{CA})$ deposited on $\mathrm{Mg}$ alloy $(\mathrm{Mg}-1 \mathrm{Ca}-$ $0.2 \mathrm{Mn}-0.6 \mathrm{Zr}$ ) by means of dipping method and the results showed no cytotoxic effects, good cell adhesion, viability and an enhancement in the promotion of the osteogenic differentiation in comparison to the uncoated substrate. Beside dip-coating, micro-arc oxidation 
(MAO) represents a commonly used method for depositing biodegradable coatings on $\mathrm{Mg}$ substrates. Zeng et al. (2016) deposited a MAO/PLLA composite the beneficial effect of the composite coating on the corrosion resistance. coating on a $\mathrm{Mg}-1 \mathrm{Li}-1 \mathrm{Ca}$ alloy, and the results revealed

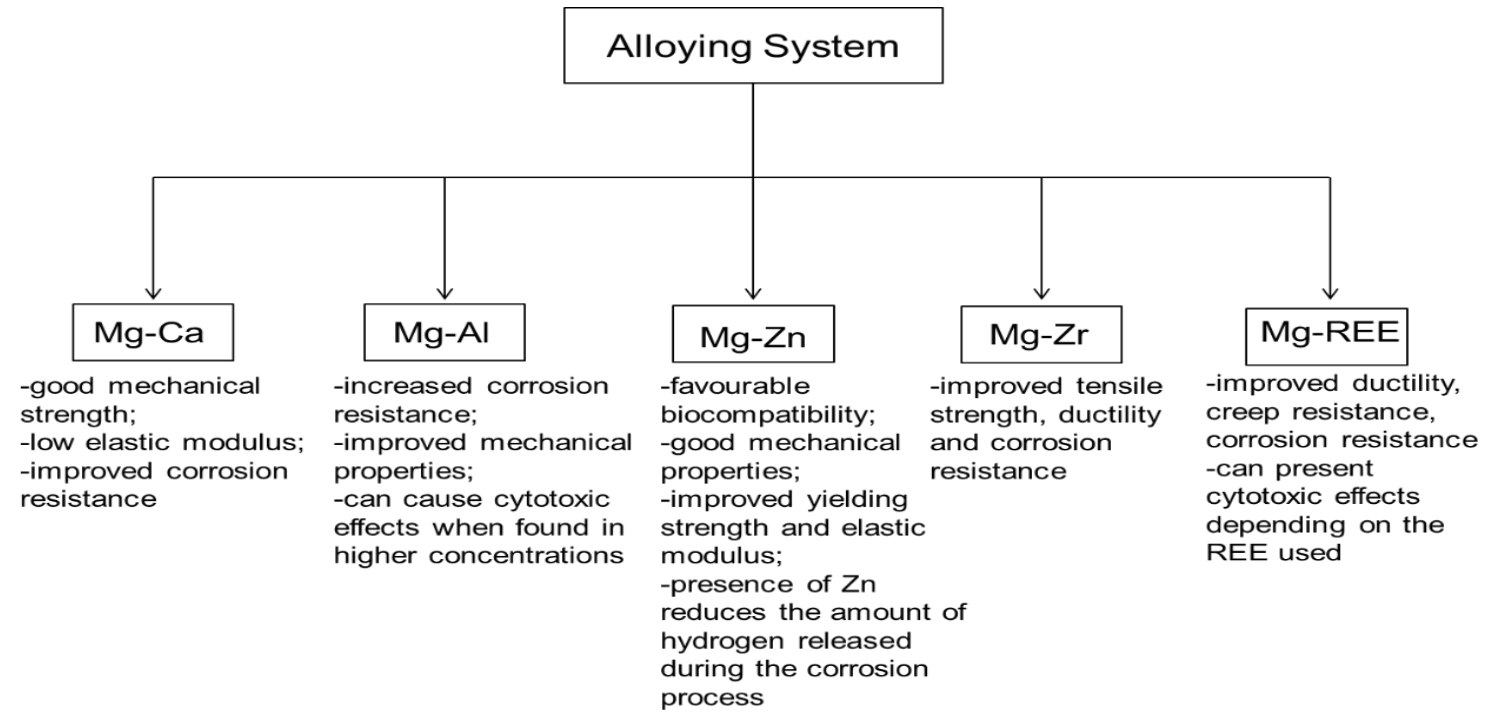

Fig. 5. Key characteristics of the Mg-based alloys

Table 3. Summary of the coatings deposited on different Mg-based alloys

\begin{tabular}{|c|c|c|}
\hline Mg SUBSTRATE & COATING/DEPOSITION METHOD & REFERENCE \\
\hline \multicolumn{3}{|c|}{ Polymer- Based Coatings } \\
\hline AM50 & Porous nHAP/PCL/ Dip coating method & Abdal-hay et al., 2013a \\
\hline AZ31B & Porous HAp/PLA/ Dip coating method & Abdal-hay et al., 2013b \\
\hline Mg-6Zn & PLGA/ Dip coating method & Li et al., 2010 \\
\hline AZ91 & PCL/dichloromethane /Dip coating method & Wong et al., 2010 \\
\hline Mg-1Ca-0.2Mn-0.6Zr & CA/ Dip coating method & Neacsu et al., 2017 \\
\hline Mg-1Li-1Ca & PLLA/ MAO technique & Zheng et al., 2016 \\
\hline AZ31/HA & PCL/HA/ Spin coating method & Hanas et al., 2018 \\
\hline Mg-1Ca & Chitosan/ Dip coating method & Gu et al., 2009 \\
\hline \multicolumn{3}{|c|}{ Calcium Phosphate - Based Coatings } \\
\hline Mg-1.2Mn-1.0Zn & Porous and netlike $\mathrm{CaP} /$ Phosphating process & Xu et al., 2009 \\
\hline Mg-0.1Ca & $\mathrm{CaP} / \mathrm{ED}$ & Zhang et al., 2010 \\
\hline Mg-4Y & CaP/Sol-gel method & Roy et al., 2011 \\
\hline AZ31 & $\mathrm{CaP} / \mathrm{Immersion}$ into $\mathrm{Ca}\left(\mathrm{No}_{3}\right)_{2}, \mathrm{NaH}_{2} \mathrm{PO}_{4}$ and $\mathrm{NaHCO}_{3}$ solutions & Cui et al., 2008 \\
\hline AZ31 & HAp/OCP/ Single step chemical deposition & Hiromoto et al., 2015 \\
\hline Mg scaffolds & $\beta$-TCP/ Immersion in $\mathrm{Na}_{2} \mathrm{HPO}_{4}$ solution & Chen et al., 2014 \\
\hline $\mathrm{Mg-0.8Ca}$ & $\beta$-TCP/ MAO technique & Sedelnikova et al., 2018 \\
\hline \multicolumn{3}{|c|}{ Hydroxyapatite - Based Coatings } \\
\hline AZ31 & HA/ Nanopodwer dispersion and ED & Kaabu Falahieh Asl et al., 2014 \\
\hline ZK60 & HA layer/ Heat treatment & Wang et al., 2013 \\
\hline Pure Mg & HA layer/ Heat treatment & Kim et al., 2014 \\
\hline AZ31 & Double layer HA-SrHA/ Microwave irradiation & Yu et al., 2016 \\
\hline Mg-2Zn-1Mn-0.5Ca & $\mathrm{Ag} / \mathrm{HA} /$ Chemical conversion & Hu et al., 2017 \\
\hline AZ31 & HA/ Biomimetic strategy with the assistance of PDA & Lin et al., 2015 \\
\hline Mg-Ca & HA/ Pulsed laser deposition & Rau et al., 2018 \\
\hline Mg-1.2Ca-4.5Zn & Bi-layered $\mathrm{SiO}_{2} / \mathrm{Ag}-\mathrm{FHAp} / \mathrm{PVD}$ and ED & Bakhsheshi-Rad et al., 2016 \\
\hline \multicolumn{3}{|c|}{ Bioactive glass - Based Coatings } \\
\hline AZ91 & Nano-sized bioactive glass/ Electrophoretic deposition method & Rojaee et al., 2014 \\
\hline WE43 & Chitosan/bioactive glass/silica/ Electrophoretic deposition method & Heise et al., 2018 \\
\hline
\end{tabular}

However, the hydrogen released during the degradation process caused an internal stress under the MAO/PLLA coating, which led to poorer mechanical properties. The in vitro evaluation showed positive results regarding cell 
adhesion and cytotoxicity. The polymer layer can also be prepared through electro-deposition. Hanas et al. (2018) studied the biodegradation and biomineralization of an electrospun nanofibrous PCL/HA composite coating deposited on the AZ31/HA metal matrix composite. The alloy was previously treated with $\mathrm{HNO}_{3}$, process that led to an improved adhesion between the coating and the surface of the alloy. The results showed an improved bioactivity and better control over the degradation process of the alloy. Apart from synthetic polymers, natural polymers like chitosan are commonly used for coating. Gu et al. (2009) developed a chitosan-based coating with a 6-layer structure that once it has been applied on a Mg-1Ca alloy, offered a better protection against the corrosion process, in comparison to the plain alloy. Xu et al. (2008) designed a chitosan-based coating that was deposited on two types of $\mathrm{Mg}$ alloys with different REE in their composition. The results showed the protective ability of the coating against the corrosion process in both cases.

Calcium Phosphate-based coatings. Thanks to its special characteristics, $\mathrm{CaP}$ is generally used in various biomedical applications, but in the context of Mg-based biomaterials only a low number of CaP-based coatings have been the subject of in vitro testing (Geng et al., 2009; $\mathrm{Xu}$ et al., 2009; Chen et al., 2014; Chen et al., 2014; Qiu et al., 2014 Neacsu et al., 2015). Xu et al. (2009) deposited a CaP layer on a Mg-Mn-Zn alloy and the in vitro results obtained suggested that the $\mathrm{CaP}$ coating was capable of providing a better surface biocompatibility and corrosion resistance. Similar results were obtained by Zhang et al. (2010). In the study they successfully prepared a $\mathrm{CaP}$ coating on a $\mathrm{Mg}-0.1 \mathrm{Ca}$ alloy by means of electrochemical deposition, and the results showed that the CaP coating was capable of improving the corrosion resistance of the alloy. Furthermore, the morphology and thickness of the coating had a significant effect on the corrosion rate of the alloy. Contradictory results regarding the improvement of the corrosion rate were published by Roy et al. (2011). In the study they prepared a CaP coating by the means of sol-gel method and the in vitro results showed no significant differences in terms of corrosion rates between the coated and the uncoated samples, while the cytotoxicity evaluation revealed an increased bioactivity for the coated samples in comparison to the uncoated ones. Moreover, it was observed that on the coated surface cells can form a matrix more rapidly than on the bare alloy. Another $\mathrm{CaP}$ phase used to date for coatings in orthopaedic devices is ortocalcium phosphate (OCP), an intermediary stage in the precipitation of hydroxyapatite (HA) and bone-like apatite (Shadanbaz et al., 2012). Cui et al. (2008) used a $\mathrm{CaP}$ coating that included in its composition HA, OCP and dicalcium phosphate in various concentrations. The coating was deposited on an AZ31 commercial alloy and its protective ability against the corrosion process in a $3.0 \%$ sodium chloride $(\mathrm{NaCl})$ solution, has been reported. Hiromoto et al. (2015) prepared a OCP and HAp coating on a Mg-3Al-1Zn (AZ31) alloy by a single step chemical deposition solution and it was observed that the corrosion of the alloy has been delayed by both OCP and HAp coatings, due to an enhancement in the precipitation process of $\mathrm{HA}$. Tricalcium phosphate (TCP) $\mathrm{Ca}_{3}\left(\mathrm{PO}_{4}\right)_{2}$ is a resorbable bioactive ceramic material, composed of two phases, $\alpha$ and $\beta$-TCP (Tan et al., 2013), with only the $\beta$ TCP phase used in the medical field in bone regeneration applications. In vitro studies revealed that TCP is an osteoconductive material (Cai et al., 2009; Chappard et al., 2010; Rokn et al., 2012) capable of enhancing the remodelling process of bone tissue by promoting the resorption process, mainly due to its small particle and interconnected sponge like microporosity (Erbe et al., 2001; Ghosh et al., 2008; Nandi et al., 2008; Hing et al., 2009; Tan et al., 2013). Geng et al. (2009) reported a lower rate of corrosion in the case of a $\beta$-TCP coating deposited on a $\mathrm{Mg}$ scaffold when compared to the bare $\mathrm{Mg}$ scaffold. Chen et al. (2014), deposited a $\beta$-TCP coating on a $\mathrm{Mg}$ alloy and the in vitro studies showed that the $\mathrm{Mg}$ alloy exhibited an osteoimmunomodulatory potential due to the presence of $\beta$-TCP coating on the surface of the alloy. Sedelnikova et al. (2018) formed a $\beta$ TCP coating by micro-arc oxidation on a $\mathrm{Mg}-0.8 \mathrm{Ca}$ alloy and the results suggested an improved corrosion rate of the coated alloy in comparison to the plain sample, a possible explanation being the presence of a ticker coating on the surface of the alloy due to the formation of HA which offers additional protection against the corrosive agents.

Hydroxyapatite-based coatings. Another $\mathrm{CaP}$ based material used for coating the surface of $\mathrm{Mg}$-based biomaterials is HA, and a number of in vitro studies have reported its beneficial properties. Kaabi Falahieh Asl et al. (2014) prepared using two different methods (nano powder dispersion and electrophoretic deposition) a HA based-coating on a commercial AZ31 alloy and showed that the deposition rate and the coating microstructure depends on the applied voltage. Therefore, by increasing the voltage, a thicker coating can be obtained, which led to an enhanced corrosion rate. Similar results were reported by Wang et al. (2013) and Kim et al. (2014). Thus, Wang et al. (2013) coated a ZK60 alloy with a HA layer using a simple conversion process-heat treatmentand reported an improvement in the corrosion resistance and cytocompatibility of the alloy when compared with the uncoated alloy. On the other hand, Kim et al. (2014) deposited a HA layer onto a Mg substrate by means of a simple treatment in an aqueous solution and observed that apart from an improved corrosion rate, a lower production of hydrogen gas released during the corrosion process. In addition, they noticed an enhancement in the cellular processes such as adhesion, proliferation and differentiation. Yu et al. (2016) used a double layer to coat a $\mathrm{Mg}$ alloy by means of microwave irradiation. The HA layer provided a better protection against the corrosion process, while the double strontium doped hydroxyapatite (SrHA) layer led to an excellent 
biomineralization process. Hu et al. (2017) coated an extruded $\mathrm{Mg}-2 \mathrm{Zn}-1 \mathrm{Mn}-0.5 \mathrm{Ca}$ alloy with an $\mathrm{Ag} / \mathrm{HA}$ composite conversion layer and the results revealed a better protection in Hank's solution and good adhesion and antibacterial properties due to the presence of $\mathrm{Ag}$. Lin et al. (2015) tailored a mussel-inspired polydopamine (PDA) induced biomimetic HA coating on the AZ31 alloy. The corrosion results revealed an increase in the corrosion resistance of the coated samples in comparison to the single PDA and HA coating. Furthermore, in vitro tests showed no potential cytotoxic effects, but a promotion of cell growth. Rau et al. (2018) deposited a HA coating on a $\mathrm{Mg}-\mathrm{Ca}$ alloy in order to obtained a controllable in vitro degradation process, and the results showed a good corrosion in SBF, suggesting a promising potential for the developed coatings.

In recent years, an attempt to replace HA coatings with fluorinate hydroxyapatite (FHA), in the field of medical devices, has been made. In vitro studies have shown that FHA exhibits better protein adsorption, a lower rate of dissolution and good biocompatibility. To note that although the number of studies involving HA coatings deposited on Ti-based materials is extensive, in the field of Mg-based materials, the research and studies are still in the initial phase. Bakhsheshi-Rad et al. (2016) deposited a bi-layered silica/silver doped fluorohydroxyapatite $\left(\mathrm{SiO}_{2} / \mathrm{Ag}-\mathrm{FHAp}\right)$ coating on a $\mathrm{Mg}$ $1.2 \mathrm{Ca}-4.5 \mathrm{Zn}$ alloy through the physical vapour deposition method (PVD) combined with electrodeposition (ED). The $\mathrm{SiO}_{2} / \mathrm{Ag}$-FHAp double layered coating showed a lower corrosion rate and significantly higher cellular viability in the long term compared to the $\mathrm{SiO}_{2}$ single layered and the plain samples.

Bioactive glass. Rojaee et al. (2014) deposited a nanosized bioactive glass through the electrophoretic deposition (EPD) method on a commercial AZ91 alloy obtained through MAO technique and the results showed that the coating had the ability to protect against corrosion and offered the substrate the ability to form apatite when immersed in SBF. Heise et al. (2018) produced a chitosan/bioactive glass/ silica coating on the WE43 alloy by means of electrophoretic deposition. The results showed that the corrosion resistance has been increased once the coating has been applied when compared to the untreated surface. Furthermore, the addition of $\mathrm{SiO}_{2}$, further enhanced the corrosion resistance of the alloy.

A summary of the most relevant properties exhibited by various coatings deposited on $\mathrm{Mg}$ based alloys for biomedical applications is shown in Fig. 6 .

\section{Surface functionalization}

In order to further improve the biological performance of the Mg-based biomaterials, bioactive molecules can be added within the composition of the anti-corrosive coatings with the purpose of inducing synergistic effects within the hybrid system (Shin et al., 2003; Saiz et al.,
2013). Immobilization of the bioactive agents in the composition of the coatings deposited on the surface of implants can improve its osteoinductive capacity, stimulate cell migration, promote cell adhesion and proliferation of osteoblasts and reduce microbial activity. In this regard a number of studies have been carried out with the purpose of modifying the surface of the biomaterials to a greater extent (Brammer et al., 2012). For example, zinc oxide ( $\mathrm{ZnO})$ has emerged as a potential candidate for surface functionalization due to its antibacterial and antifungal properties. Mousa et al. (2018) dispersed zinc oxide nanoparticles ( $\mathrm{ZnO}$ NPs) within a new biodegradable layer composed of PLA. The newly developed coating was deposited through a dipcoating method on the AZ31 alloy and the results obtained suggested that the multifunctional coating exhibited anticorrosive and antibacterial properties, with an improved cell adhesion and proliferation. Similar results regarding the addition of $\mathrm{ZnO}$ NPs within the composition of anti-corrosive coatings were obtained by Kim et al. (2016). In their study, a PCL/ZnO coating was applied on the AZ31 substrate by means of electrospinning and the results revealed a superior corrosion resistance, cell attachment and proliferation for the coated samples in comparison to the uncoated ones. Moreover, by increasing the $\mathrm{ZnO}$ NPs content, an increase in the corrosion resistance and cell adhesion could be observed. Aside from metallic nanoparticles, different antibiotics, anti-inflammatory drugs and growth factors have been immobilized within coatings in order to enhance the corrosion behaviour and cell response. Rezk et al. (2018) incorporated simvastatin (SIM), a drug with positive effects on bone formation (Piskin et al., 2007), into a HA-NPs/PCL composite coating deposited on the AZ31 substrate via electrospinning. The results indicated a reduced degradation process and an enhanced bone tissue regeneration. The in vitro evaluation showed that the additional presence of SIM within the composite coating led to a higher cell adhesion and proliferation on the implant surface. Pandele et al. (2018) immobilized resveratrol (Res) onto a cellulose acetate (CA) polymeric membrane deposited onto a $\mathrm{Mg}-1 \mathrm{Ca}-0.2 \mathrm{Mn}-0.6 \mathrm{Zr}$ alloy and the in vitro results showed its ability to support preosteoblast viability and proliferation. Moreover, the addition of Res within the composition of the coating led to a significant increase in alkaline phosphatase activity and extracellular matrix (ECM) mineralization.

\section{In vivo studies of currently developed Mg-} based biomaterials

A recent study showed that, annually, more than one million people suffer from broken/fractured bones in the USA alone, some of these fractures being too complex for external medical treatment, therefore making the need of bone fixtures such as screws, plates, pins, wires made of Mg-based alloys necessary. 
During recent years, the effect of alloying and surface treatments on cells response has been evaluated through in vitro studies, but in some cases, the in vitro results were not sufficient in order to predict the in vivo behaviour of the biomaterial; therefore, further in vivo studies were required. As a vast number of $\mathrm{Mg}$-based biomaterials have been tested in vivo, this section will present recent literature since 2010 to now (Table 4).

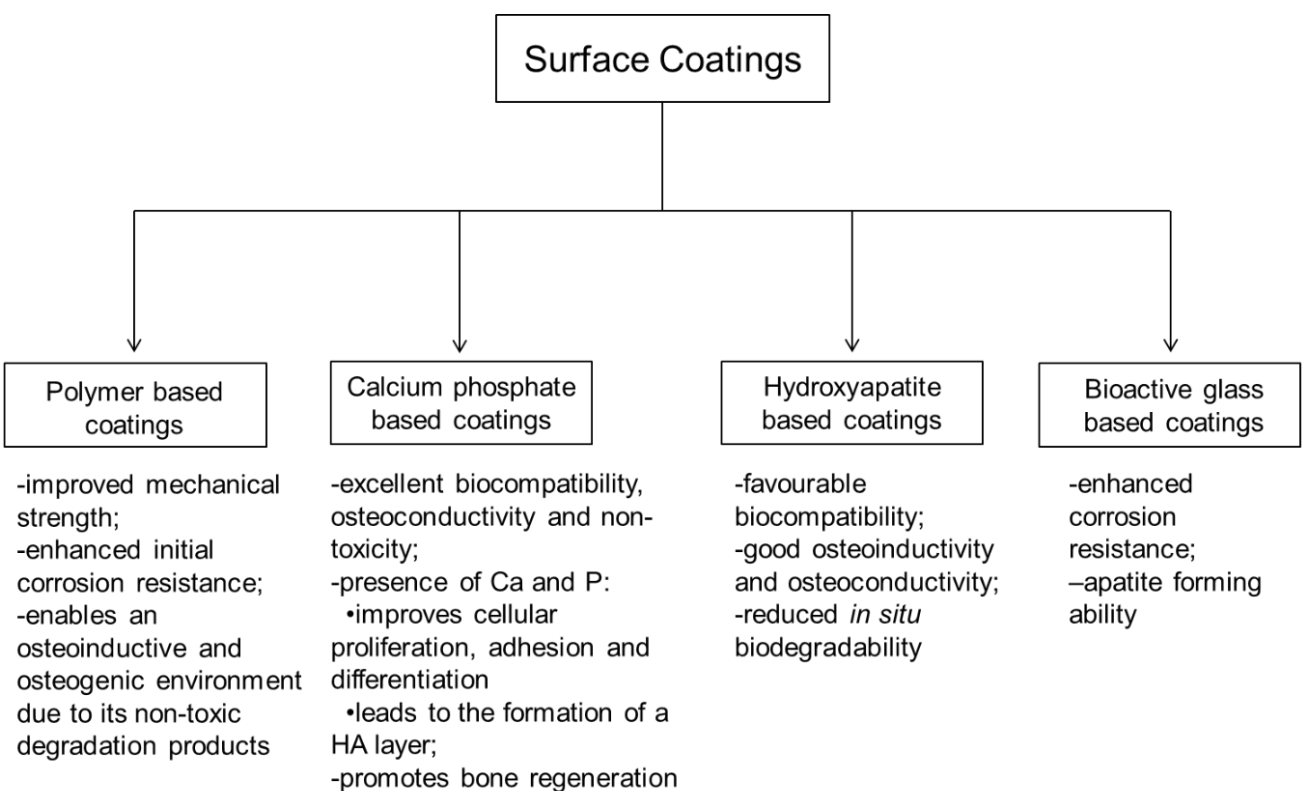

Fig. 6. Mg based coatings characteristics

Table 4. Summary of relevant in vivo studies regarding Mg-based biomaterials

\begin{tabular}{|c|c|c|c|}
\hline MG SUBSTRATE & SPECIES & RESULTS & REFERENCE \\
\hline \multicolumn{4}{|c|}{ Mg alloys } \\
\hline $\begin{array}{l}\text { Mg-0.8Ca; LAE442 } \\
\text { WE43 }\end{array}$ & Rabbit & $\begin{array}{l}\text { LAE442 exhibited a good corrosion resistance and initial } \\
\text { strength while the other two alloys were deemed not suitable } \\
\text { for bone implant applications. }\end{array}$ & Krause et al., 2010 \\
\hline WE43 & Rat & Improved mechanical strength and osseointegration. & Castellani et al., 2011 \\
\hline ZEK100 & Rabbit & $\begin{array}{l}\text { In short term it exhibited a low degradation rate and stability } \\
\text { but on long term it led to bone alteration after complete } \\
\text { degradation. }\end{array}$ & Dziuba et al., 2013 \\
\hline $\begin{array}{l}\text { Mg-5Zr; Mg-5Zr-Ca } \\
\text { Mg-2Zr-5Sr; } \\
\text { Mg-Zr-2Sr }\end{array}$ & $\begin{array}{c}\text { New- } \\
\text { Zealand } \\
\text { White rabbit }\end{array}$ & $\begin{array}{l}\text { Improved corrosion resistance due to the addition of } \mathrm{Sr} \text { in } \\
\text { the } \mathrm{Mg} \text { matrix. }\end{array}$ & $\begin{array}{l}\text { Mushahary et al., } \\
2013\end{array}$ \\
\hline Mg-1.0-0.5Sr & Rat & $\begin{array}{l}\text { Mild inflammatory response and new bone formation after } 6 \\
\text { weeks of implantation. }\end{array}$ & Berglund et al., 2016 \\
\hline Mg-3.5Li-0.5Ca & Mouse & Enhanced new bone formation and cortical bone thickness. & Xia et al., 2018 \\
\hline Mg-Ag-Y & $\begin{array}{c}\text { Sprague } \\
\text { Dawley rat }\end{array}$ & $\begin{array}{l}\text { Enhanced new bone formation and corrosion resistance due } \\
\text { to the presence of } Y \text {. }\end{array}$ & Yu et al., 2018 \\
\hline Mg-Y-Zn-Zr-Ca & Rat & Favourable biocompatibility but poor corrosion resistance. & Chou et al., 2019 \\
\hline Mg-1.8Zn-0.2Gd & $\begin{array}{c}\text { Sprague } \\
\text { Dawley rat }\end{array}$ & $\begin{array}{l}\text { Good biocompatibility but poor corrosion resistance on long } \\
\text { term. }\end{array}$ & Bian et al., 2018 \\
\hline $\mathrm{Mg}-5.25 \mathrm{Zn}-0.6 \mathrm{Ca}$ & Mouse & $\begin{array}{l}\text { Favourable biocompatibility and enhanced new bone } \\
\text { formation. The corrosion rate was influenced by the } \\
\text { implantation region and the surgical trauma. }\end{array}$ & Gu et al., 2018 \\
\hline AZ31 & Sheep & $\begin{array}{l}\text { The corrosion rate was mainly influenced by the } \\
\text { implantation region. }\end{array}$ & Willbold wt al., 2011 \\
\hline Mg-Zn & Rabbit & The corrosion rate was influenced by the implantation site. & Han et al., 2014 \\
\hline $\begin{array}{l}\text { Mg-2Sr-Ca } \\
\text { Mg-2Sr-Zn }\end{array}$ & Mouse & $\begin{array}{l}\text { Improved corrosion resistance and enhanced new bone } \\
\text { formation. }\end{array}$ & Chen et al., 2020 \\
\hline
\end{tabular}




\begin{tabular}{|c|c|c|c|}
\hline Mg-1Sc & Rabbit & $\begin{array}{l}\text { Enhanced osteogenic process and low corrosion rate after } 5 \\
\text { months in situ. }\end{array}$ & Lin et al., 2020 \\
\hline \multicolumn{4}{|c|}{ Surface coatings } \\
\hline Mg-Zn-Ca/ CA-defHA & Rabbit & $\begin{array}{l}\text { Improved corrosion resistance and new bon formation for } \\
\text { the coated alloy. }\end{array}$ & Wang et al., 2011 \\
\hline AZ31/ Hap/OCP & Mouse & $\begin{array}{l}\text { Supressed FBR and low degradation rates for both coated } \\
\text { alloys. }\end{array}$ & Hiromoto et al., 2015 \\
\hline $\mathrm{Mg}-6 \mathrm{Zn} / \beta-\mathrm{TCP}$ & Rabbit & $\begin{array}{l}\text { Favourable biocompatibility and improved new bone } \\
\text { formation. }\end{array}$ & Yu et al., 2012 \\
\hline $\begin{array}{l}\beta \text {-TCP/Mg- } \\
\text { Zn/dopamine/gelatine/ } \\
\text { rhBMP-2 }\end{array}$ & $\begin{array}{c}\text { New } \\
\text { Zealand } \\
\text { White } \\
\text { rabbit } \\
\end{array}$ & $\begin{array}{l}\text { Improved corrosion resistance and new bone formation } \\
\text { coupled with a favourable biocompatibility. }\end{array}$ & Liu e al., 2020 \\
\hline Mg/HAT & Rabbit & $\begin{array}{l}\text { Improved corrosion resistance and new bone formation. } \\
\text { Furthermore, an enhanced osteogenic process and supressed } \\
\text { osteoclastogenic process was observed. }\end{array}$ & Li et al., 2018 \\
\hline ZK60/Ca-Sr-P & Rabbit & $\begin{array}{l}\text { Enhanced new bone formation and osseointegration coupled } \\
\text { with a low corrosion rate. }\end{array}$ & Makkar et al., 2020 \\
\hline Mg-Sr/Sr-Ca-P & Rabbit & Improved corrosion rate and new bone formation. & Han et al., 2016 \\
\hline $\mathrm{Mg}-\mathrm{Nd}-\mathrm{Zn}-\mathrm{Zr} / \mathrm{SrHPO}_{4}$ & Rat & $\begin{array}{l}\text { Improved new bone formation and corrosion resistance } \\
\text { coupled with an enhanced fracture healing. }\end{array}$ & Wang et al., 2020 \\
\hline $\begin{array}{l}\text { Mg-1Ca-0.2Mn- } \\
0.6 \mathrm{Zn} / \mathrm{AC}\end{array}$ & Rat & Improved bone regeneration and no scar tissue. & Neacsu et al., 2017 \\
\hline AZ31/MMT-BSA & Rat & Improved structural integrity and no toxic effects in the host. & Wang et al., 2019 \\
\hline AZ31B/Fluoride & Rabbit & Improved corrosion resistance and osteogenic activity. & Sun et al., 2016 \\
\hline $\mathbf{M Z Z / M g F}{ }_{2}$ & Rabbit & $\begin{array}{lccc}\text { Improved corrosion } & \text { resistance, } & \text { cytocompatibility, } \\
\text { osteoinductivity and osteogenic activity. }\end{array}$ & Li et al., 2017 \\
\hline AZ91/akermanite/PEO & Rabbit & Enhanced new bone formation and reduced inflammation. & Razavi et al., 2014 \\
\hline $\begin{array}{l}\text { AZ91/diopside } \\
\left(\mathrm{CaMgSi}_{2} \mathrm{O}_{6}\right)\end{array}$ & Rabbit & $\begin{array}{l}\text { Reduced gas bubbles formation and enhanced new bone } \\
\text { formation. }\end{array}$ & Razavi et al., 2014 \\
\hline
\end{tabular}

\section{Mg-Alloys}

As mentioned before, pure $\mathrm{Mg}$ possesses insufficient mechanical strength and a rapid corrosion rate in physiological environments. Therefore, the development of new $\mathrm{Mg}$ alloys with lower corrosion rates and improved mechanical properties is desirable. Alloys such as AZ91, LAE442, WZ21, and WE43 have been widely tested throughout the years, and the results of the in vivo studies have shown that, at some extent, those Mg alloys can be used as potential biomaterials for bone implants. Krause et al. (2010) investigated three different types of Mg-based alloys (MgCa0.8; LAE442; WE43) in terms of mechanical strength and degradation process for the use as bone implants and the results revealed that the $\mathrm{MgCa} 0.8$ alloy system exhibited a low initial strength and a rapid corrosion rate, while the LAE442 alloy degraded slowly and showed good initial strength. The last Mgbased biomaterial, WE43, exhibited an unpredictable in vivo behaviour; therefore, it was deemed as not safe for use as a bone implant. Contradictory results regarding the WE43 alloy were presented by Castellani et al. (2011) in their study, where rods based on WE43 alloy have been implanted into the cortical bone of rats and the results showed a higher mechanical stability and better osseointegration when compared to Ti based pins. Dziuba et al. (2013) tested the long-term biocompatibility and the degradation behaviour of a ZEK100 alloy and he observed that even if, initially, the material showed stability and a lower degradation rate, further testing revealed bone alterations after complete degradation due to an increase in the number of osteoclasts and a poor imbalance in the bone turn-over process. Even though the in vivo results were promising, those alloys contain in their composition $\mathrm{Al}$ which possesses neurotoxicity and, hence, the development of alloys with more biocompatible elements, such as $\mathrm{Zn}, \mathrm{Sr}, \mathrm{Li}, \mathrm{Mn}, \mathrm{Ca}$ is desirable. Mushahary et al. (2013) used different $\mathrm{Mg}$ alloying systems (Mg-5Zr; Mg-5Zr-Ca; Mg-2Zr-5Sr; $\mathrm{Mg}-\mathrm{Zr}-2 \mathrm{Sr}$ ) in order to evaluate the effects of the alloying elements on the in vivo compatibility of these materials. Their results indicated that the addition of $\mathrm{Sr}$ in the alloy increased the corrosion resistance and early bone formation, with the additional remark that $2 \%$ wt Sr was detected as the optimal concentration for a good osseointegration process. Berglund et al. (2016) implanted a Mg-1.0wt\%-0.5wt\% Sr alloy into the rat tibia 
with the purpose of assessing the local tissue response and the results showed a mild inflammatory response and new bone tissue formation after 6 weeks of implantation despite an early gas formation and increased osteoclasts activity. Xia et al. (2018) developed ternary Mg-3.5Li$0.5 \mathrm{Ca}$ alloys and assessed their in vivo performance. The results showed that the alloy enhanced the cortical bone thickness and promoted the new bone formation in comparison to the $\mathrm{Ti}$ alloy and pure $\mathrm{Mg}$ alloy, mainly due to the presence of $\mathrm{Li}$ ions released from the alloy. Chen et al. (2020) developed two different Mg alloying systems ( $\mathrm{Mg}-2 \mathrm{Sr}-\mathrm{Ca}$ and $\mathrm{Mg}-2 \mathrm{Sr}-\mathrm{Zn}$ ) in order to investigate their in vivo corrosion rates and biocompatibility. In terms of corrosion, the newly developed alloys exhibited a lower corrosion rate than that of $\mathrm{Mg}-2 \mathrm{Sr}$ alloy. Furthermore, both alloys could promote bone mineralization without causing any side effects. Lin et al. (2020) implanted into a rabbit's femur a newly developed $\mathrm{Mg}-1 \mathrm{Sc}$ alloy in order to evaluate its behaviour and the results showed an enhanced osteogenic process compared to the Ti control, coupled with a low corrosion rate - the implant maintained its integrity even after 5 months. The use of REE as alloying elements is controversial from a medical point of view but elements such as $\mathrm{Y}, \mathrm{Nd}, \mathrm{Gd}$ can improve the strength, ductility and corrosion resistance of the material. Yu et al. (2018) assessed the in vivo corrosion behaviour and osteogenic potential of a novel $\mathrm{Mg}-\mathrm{Ag}-\mathrm{Y}$ alloy and observed that the corrosion rate of the alloying system was significantly lower and more bone tissue was formed around the implant in comparison to pure $\mathrm{Mg}$, mostly due to the presence of the $\mathrm{Y}$ element. Also, using $\mathrm{Y}$ as an alloying element, Chou et al. (2019) evaluated the in vivo performance of a $\mathrm{Mg}-\mathrm{Y}-\mathrm{Zn}-\mathrm{Zr}-\mathrm{Ca}$ alloy and reported positive results regarding its biocompatibility but poor corrosion resistance due to the surrounding blood vessels and stress related corrosion that appeared at the osteotomy site of high mechanical loading. Bian et al. (2018) developed a novel Mg-1.8Zn$0.2 \mathrm{Gd}$ alloy and evaluated its in vivo degradation. The results obtained revealed that the implant kept its integrity up to 2 months but at 6 months postimplantation serious degradation could be observed. However, in terms of biocompatibility and osteoconductivity, the implant got integrated into the surrounding bone tissue after only 2 months, suggesting its good biocompatibility. Gu et al. (2018) investigated the corrosion and the biocompatibility of the newly developed Mg-5.25Zn-0.6Ca alloy for the purpose of orthopaedic applications. The in vivo results revealed a promising biocompatibility with an enhanced new bone formation due to an increase in the $\mathrm{Mg}$ ion concentration which in combination with the local increased $\mathrm{pH}$, lead to an improved nucleation rate of apatite and mineralization. Despite this, the alloying system exhibited an increased in vivo corrosion compared with the in vitro degradation rates. This led to the conclusion that the corrosion rate was influenced mainly by the implantation regions and the surgical trauma generated by the drilling process that caused a reduction in the oxygen tension and local $\mathrm{pH}$ that resulted in a faster corrosion process. The degradation behaviour of different implantations sites has been approached by Willbold et al. (2011), which published a paper where the degradation rate of an AZ31 alloy implanted in different regions (the head of the $\mathrm{Mg}$ based screw was covered by soft tissue while the screw thread was located in the hip bone) has been investigated. The results showed an increased degradation with a thicker layer of corrosion at the head of the screw compared to the rest of the screw, supporting the idea that different biological environments can cause different degradation behaviours. These findings were supported by another study conducted by Han et al. (2014), where a $\mathrm{Mg}-\mathrm{Zn}$ alloy has been implanted in different parts of the femoral condyle and the in vivo degradation behaviours of these different environments were compared. Their findings suggested that the implant in vivo degradation process depends on the implantation site, especially in those areas that have distinct biological functions. Thus, the corrosion rate of the implant decreased in the following order: soft tissue, less trabecular bone, more trabecular bone and cortical bone.

\section{Surface coatings}

Other in vivo studies focused on the effectiveness of surface treatments such as coating deposition, which could improve the surface biocompatibility and corrosion resistance of the implant. For example, Wang et al. (2011) evaluated the degradation process and bone response of a $\mathrm{Mg}-\mathrm{Zn}-\mathrm{Ca}$ alloy coated with Ca-deficienthydroxyapatite (Ca-defHA) and the in vivo results showed that, after 8 weeks of implantation, the coated alloy exhibited a slower degradation rate than the uncoated alloy and the presence of new bone tissue around the implant, demonstrating its good osteoconductivity. Hiromoto et al. (2015) deposited HAp and OCP coatings on a commercial AZ31 alloy and the degradation process and biocompatibility of the coated materials was investigated. In terms of corrosion, on both materials the process was microscopically localized (visible round pits and micropits under the coatings) while, in terms of inflammation, the foreign-body reaction was supressed by both coatings with the soft tissue directly attached to the coatings, demonstrating the high potential of the coatings as biodegradable materials for bone implants. Yu et al. (2012) deposited a $\beta$-TCP coating on a $\mathrm{Mg}-6 \mathrm{Zn}$ alloy in order to evaluate its in vivo degradation behaviour and the results indicated that the coated alloy exhibited favourable biocompatibility and was capable of improving the concrescences of the prebroken bone tissue. Liu et al. (2020) deposited a newly obtained dopamine/gelatine/recombinant human bone morphogenetic protein-2 (rhBMP-2) coating on a porous $\beta-\mathrm{TCP} / \mathrm{Mg}-\mathrm{Zn}$ composite in order to investigate the biomaterial's in vivo behaviour. The results showed an improved corrosion resistance coupled with a favourable biocompatibility and improved new bone formation. Li et 
al. (2018) developed a bilayer-structured coating composed of an outer layer of HA and an inner layer of pores-sealed $\mathrm{MgO}$ for a pure $\mathrm{Mg}$ implant. The results indicated a long term stability and lower corrosion rate for the coated implant as well as an enhanced new bone formation. Makkar et al. (2020) investigated the in vivo behaviour of a strontium doped calcium phosphate $(\mathrm{Ca}$ Sr-P) coating deposited on a ZK60 Mg-based alloy and the results showed a lower degradation rate for the coated sample in comparison to the bare alloy. Furthermore, the newly developed coating led to an improved bone formation and osseointegration after 4 weeks of implantation. Similar results regarding $\mathrm{Sr}$-coated $\mathrm{Mg}$ based alloys were reported by Han et al. (2016) and Wang et al. (2020). E.g., Han et al. (2016) deposited a Sr$\mathrm{Ca}-\mathrm{P}$ coating on a $\mathrm{Mg}-\mathrm{Sr}$ alloy and the results obtained suggested that the coated implant was capable of promoting new bone formation and retard the degradation process. On the other hand, Wang et al. (2020) developed a newly $\mathrm{Sr}-\mathrm{HPO}_{4}$ coating for a $\mathrm{Mg}-\mathrm{Nd}-\mathrm{Zn}-\mathrm{Zr}$ alloy and proved that the coating was capable to slow down the corrosion process of the implant and to improve the formation of new bone tissue as well as to enhance fracture healing without causing any side effects in the host. Neacsu et al. (2017) deposited a coating based on $\mathrm{AC}$ on a newly developed $\mathrm{Mg}-1 \mathrm{Ca}-0.2 \mathrm{Mn}-0.6 \mathrm{Zr}$ alloy and the results suggested that the coated alloy was more efficient in promoting bone regeneration in comparison to the bare alloy. Furthermore, the coated implant led to a mild to moderate fibrosis with less bone destruction, while the bare implant led to scar formation. Wang et al. (2019) prepared a montmorillonite/bovine serum albumin (MMT-BSA) coating on the AZ31 alloy and the in vivo results indicated that the coated implant was capable of maintaining its structural integrity within 120 days and no toxic side effects were observed. Sun et al. (2016) investigated the in vivo effects of a fluorine coated $\mathrm{Mg}$ alloy implanted into a rabbit mandibular and femur and the results suggested a lower degradation rate and an improved osteogenic activity as compared to the bare alloy. Moreover, the coating was capable of regulating the collagen type I and BMP-2 expression. Similar results were reported by $\mathrm{Li}$ et al. (2017). They investigated a $\mathrm{MgF}_{2}$-coated $\mathrm{Mg}-\mathrm{Zn}-\mathrm{Zr}$ alloy and showed an improved corrosion resistance coupled with an enhanced cytocompatibility, osteoinductivity and osteogenesis for the coated alloy in comparison to the bare one. Razavi et al. (2014) prepared a nanostructured akermanite $\left(\mathrm{Ca}_{2} \mathrm{MgSi}_{2} \mathrm{O}_{7}\right)$ coating on the AZ91 alloy in order to investigate its in vivo behaviour. The coated alloy showed a lower post-surgery inflammatory response and an enhanced new bone formation compared to the bare alloy. Another study by Razavi et al. (2014) involved the preparation of a nanostructured diopside (CaMgSi2O6) coating on the AZ91 alloy by means of MAO and EDP. The results from the in vivo study suggested that the coated implant promoted new bone formation and reduced the formation of gas bubbles at the implantation site.

\section{Clinical applications of Mg-based biomaterials}

Mg-based biomaterials' clinical applications do not differ very much from the historically attempts, with the research still focused on the two main fields of investigation associated with the development of $\mathrm{Mg}$ based biodegradable implants for orthopaedic and cardiovascular applications. However, the development of Mg-based implantable devices for cardiovascular applications has been more successful, with a vast number of both animal and human studies conducted on this subject. The first pioneering work in the field of biodegradable stents was conducted in 2003, were AZ31 $\mathrm{Mg}$ alloy stents were implanted into the coronary artery of domestic pigs for 56 days and the results obtained showed the promising potential of $\mathrm{Mg}$ based biomaterials in cardiovascular applications (Heublein et al., 2003). Despite this, the degradation rate of the stents was less than desirable and the follow-up studies showed similar results (Waksman et al., 2006; Waksman et al., 2007). In order to solve this problem, the research focused on strategies such as surface coating, alloying and adjustment of the stent geometry, which allowed the control of the degradation rate. The very first commercially available stent was composed of 93 wt.\% $\mathrm{Mg}$ and 7 wt.\% REE (AMS-1, Biotronik AG, Bulach, Switzerland), and even though it exhibited a high degradation rate, the results obtained in the preclinical studies indicated a good endotheliazation (Campos et al., 2013). Further on, Biotronik released on the market two improved metallic stents based on $\mathrm{Mg}$ alloys with slower degradation rates. AMS-2 (DREAMS-1-Drug Eluting AMS) stent was manufactured with additionally incorporated anti-proliferative drugs that targeted neointimal hyperplasia and restenosis, while the AMS-3 stent (DREAMS-2) was a modification of DREAMS-1 with a newly developed (PLLA) coating for a controlled release of the anti-proliferative drugs and a slower degradation rate (Bowen et al., 2016). The very first in man study (BIOSOLVE-I trial) was conducted on 46 patients with different lesions and its purpose was to evaluate the performance and safety of a first-generation of drug-eluting Mg-based bioresorbable scaffolds (BRS) (Campos et al. 2013). Over the last years, several Mg alloys such as AE21 (2 wt.\% $\mathrm{Al}$ and 1 wt.\% REE) (Heublein et al., 2003), WE43 (4 wt.\% Y) and 3 wt.\% REE) (Peeters et al., 2005; Waksman et al., 2006), AM60 (6 wt.\% $\mathrm{Al}$ and 0.3 wt.\% Mn) (Levesque et al., 2003), have been evaluated for cardiovascular applications. Additionally, human clinical trials reported good results after Mg-based stent implantation. In a clinical study, a $\mathrm{Mg}$ alloy stent was used with success in an attempt to ligate a left pulmonary artery in a premature baby 
(Zartner et al., 2005). Follow-up clinical studies have reported the use of $\mathrm{Mg}$-based stents in both babies and adults with good results and a complete degradation of the stents in the following 4 months after the implantation (Schranz et al., 2006; Barlis et al., 2007; Erbel et al., 2007; Waksman et al., 2009; Schmidt et al., 2016). In terms of orthopaedic applications, the development of Mg-based implantable devices is further behind, with very few Mg-based materials being investigated as clinically relevant implants. Current studies reported the use of $\mathrm{Mg}$ based biomaterials for different types of implantable fixation devices such as plates, screws, pins and fasteners (Witte et al., 2005; Staiger et al., 2006; Witte et al., 2007; Zhang et al., 2007). The first Mg screw (Magnezix ${ }^{\circledR}$ ) approved by the FDA was manufactured for the fixation of bone fragments (Seitz et al., 2016; Ibrahim et al., 2017) and since its introduction to the market, more than 4000 screws were sold around the world. Compared to the already commercially available $\mathrm{Ti}$, the newly developed $\mathrm{Mg}$ screw was free of $\mathrm{Al}$ (Ibrahim et al., 2017) and possessed favourable mechanical properties such as a similar elastic modulus to natural bone and improved yielding and tensile strengths. In terms of animal studies, different $\mathrm{Mg}$-based implants have been used in both small and large animal models (Gu et al., 2012; Chaya et al., 2015; Zhao et al., 2017; Wang et al., 2017; Tian et al., 2018; Wang et al., 2018). However, the studies were mostly rudimentary, lacking the evaluation of the implant in a functional sense. They did not simulate clinical scenarios or validate potential clinical applications of the $\mathrm{Mg}$-based implants (Wancket L.M., 2015). Table 5 summarises the representative animal studies performed so far in regards of the bio-efficiency and biosafety of the Mg-based implants. In terms of human pre-clinical studies, Windhagen et al. (2013) studied the differences between Magnezix ${ }^{\circledR}$ and $\mathrm{Ti}$ screws in 26 patients in terms of biological effect and comfort during a 6 month-period of time. No significant differences were observed between the two testes samples, with only 1 patient showcasing a poor biological reaction due to a long-lasting wound problem. However, despite the great progress made in the field of $\mathrm{Mg}$-based implantable devices, a significant effort still has to be made in order to obtain a product that proves effective from all points of view.

Table 5. Animal studies on Mg-based biomaterials as potential orthopaedic implants

\begin{tabular}{|c|c|c|c|c|c|c|}
\hline Mg alloy & Device & Surgery & Species & Results & $\begin{array}{l}\text { Clinical } \\
\text { relevance }\end{array}$ & Reference \\
\hline Mg-Sr & Screw & $\begin{array}{l}\text { Implantation } \\
\text { into the } \\
\text { femoral cavity }\end{array}$ & $\begin{array}{l}\text { Guinea } \\
\text { pig }\end{array}$ & $\begin{array}{l}\text { Enhanced new bone } \\
\text { formation }\end{array}$ & $\begin{array}{l}\text { Evaluation of the } \\
\text { bone response }\end{array}$ & Witte et al., 2005 \\
\hline $\begin{array}{l}\text { Mg alloy } \\
\text { AZ91 }\end{array}$ & Pin & $\begin{array}{l}\text { Implantation } \\
\text { into the } \\
\text { femoral shaft }\end{array}$ & Rabbit & $\begin{array}{ll}\text { Enhanced new bone } \\
\text { formation coupled with } \\
\text { no } & \text { inflammatory } \\
\text { process } & \\
\end{array}$ & $\begin{array}{l}\text { Evaluation of the } \\
\text { bone response }\end{array}$ & Wong et al., 2010 \\
\hline Mg-Zn & Pin & Cortical bone & Rat & $\begin{array}{l}\text { Enhanced } \\
\text { osteoconductive } \\
\text { properties }\end{array}$ & $\begin{array}{l}\text { Evaluation of the } \\
\text { bone response }\end{array}$ & Kraus et al., 2012 \\
\hline Mg-Y & Scaffold & $\begin{array}{l}\text { Implantation } \\
\text { into the } \\
\text { femoral } \\
\text { condyle }\end{array}$ & Rabbit & $\begin{array}{l}\text { No FBR or gas } \\
\text { formation }\end{array}$ & $\begin{array}{l}\text { Potential } \\
\text { treatment for the } \\
\text { repair of bone } \\
\text { defects }\end{array}$ & Bobe et al., 2013 \\
\hline Mg-Zn-Ca & Screw & $\begin{array}{l}\text { Implantation } \\
\text { into the } \\
\text { femoral } \\
\text { condyle }\end{array}$ & Rabbit & $\begin{array}{ll}\text { Reduced } & \text { gas } \\
\text { production } & \text { and } \\
\text { favourable } & \\
\text { biocompatibility } & \\
\end{array}$ & $\begin{array}{l}\text { Evaluation of the } \\
\text { bone response }\end{array}$ & Cha et al., 2013 \\
\hline Pure Mg & $\begin{array}{l}\text { Screw and } \\
\text { plate }\end{array}$ & Ulna fractures & Rabbit & $\begin{array}{l}\text { Enhanced bone } \\
\text { formation around the } \\
\text { implantation situ }\end{array}$ & $\begin{array}{l}\text { Treatment for } \\
\text { bone fractures in } \\
\text { weight bearing } \\
\text { sites }\end{array}$ & Chaya et al., 2015 \\
\hline Pure Mg & Screw & $\begin{array}{l}\text { Femoral } \\
\text { intracondylar } \\
\text { fractures }\end{array}$ & Rabbit & $\begin{array}{l}\text { Improved healing } \\
\text { process of the fracture }\end{array}$ & $\begin{array}{l}\text { Treatment for } \\
\text { intra-articular } \\
\text { fracture }\end{array}$ & Han et al., 2015 \\
\hline $\begin{array}{l}\text { Mg alloy } \\
\text { LAE442 }\end{array}$ & $\begin{array}{l}\text { Intermedullary } \\
\text { interlocked } \\
\text { screw/nail }\end{array}$ & $\begin{array}{l}\text { Implantation } \\
\text { into the bone } \\
\text { marrow } \\
\text { medullary } \\
\text { cavity }\end{array}$ & Sheep & $\begin{array}{l}\text { Favourable } \\
\text { biocompatibility }\end{array}$ & $\begin{array}{l}\text { Evaluation of the } \\
\text { in situ } \\
\text { biocompatibility }\end{array}$ & $\begin{array}{l}\text { Rossing et al., } \\
2015\end{array}$ \\
\hline
\end{tabular}




\begin{tabular}{|c|c|c|c|c|c|c|}
\hline Mg-Ag & $\begin{array}{l}\text { Intramedullary } \\
\text { pin }\end{array}$ & $\begin{array}{l}\text { Femoral } \\
\text { fractures }\end{array}$ & Mouse & $\begin{array}{l}\text { Abundant callus } \\
\text { formation around the } \\
\text { fracture }\end{array}$ & $\begin{array}{l}\text { Treatment for } \\
\text { bone fractures in } \\
\text { weight bearing } \\
\text { sites }\end{array}$ & Jahn et al., 2016 \\
\hline Pure Mg & $\begin{array}{l}\text { Intramedullary } \\
\text { pin }\end{array}$ & $\begin{array}{l}\text { Femoral } \\
\text { fractures }\end{array}$ & Rat & Improved bone healing & $\begin{array}{l}\text { Treatment for } \\
\text { fracture healing } \\
\text { in heavy weight- } \\
\text { bearing sites }\end{array}$ & Zhang et al., 2016 \\
\hline Pure Mg & $\begin{array}{l}\text { Interference } \\
\text { screw }\end{array}$ & $\begin{array}{l}\text { Anterior } \\
\text { cruciate } \\
\text { ligament } \\
\text { (ACL) } \\
\text { reconstruction }\end{array}$ & Rabbit & $\begin{array}{l}\text { Enhanced } \\
\text { mineralization between } \\
\text { the bone and tendon } \\
\text { leading to an improved } \\
\text { tendon graft healing }\end{array}$ & $\begin{array}{l}\text { Treatment for } \\
\text { patients with } \\
\text { ACL tears }\end{array}$ & Wang et al., 2017 \\
\hline Mg-Zn-Ca & Pin and screw & $\begin{array}{l}\text { Implantation } \\
\text { into the bone } \\
\text { shaft }\end{array}$ & $\begin{array}{l}\text { Rat and } \\
\text { sheep }\end{array}$ & No side effects & $\begin{array}{lr}\text { Treatment } & \text { for } \\
\text { bone defects in } \\
\text { children }\end{array}$ & Grun et al., 2018 \\
\hline $\mathrm{Mg}-\mathrm{Zn}-\mathrm{Sr}$ & $\begin{array}{l}\text { Interference } \\
\text { screw }\end{array}$ & $\begin{array}{l}\text { ACL } \\
\text { reconstruction }\end{array}$ & Rabbit & $\begin{array}{l}\text { Enhanced bone } \\
\text { ingrowth and reduced } \\
\text { loss of the peri-tunnel } \\
\text { bone tissue }\end{array}$ & $\begin{array}{lr}\text { Treatment } & \text { for } \\
\text { patients with } & \text { ACL } \\
\text { reconstruction }\end{array}$ & Wang et al., 2018 \\
\hline
\end{tabular}

\section{Conclusions}

This present study provides a review of the specialized literature on the biodegradable $\mathrm{Mg}$-based biomaterials and the progress that has been made in the last decades in the field of bone regenerative medicine in terms of strategies to improve the performance of these biomaterials as well as the most recent in vitro, in vivo and clinical studies. In the last decades, the shift from commercial alloys for engineering applications to $\mathrm{Mg}$ based biomaterials for biological applications has been made. The newly developed Mg-based biomaterials should provide low/no toxicity levels, appropriate mechanical properties, good biocompatibility and a suitable degradation rate. In order to achieve these characteristics, alloying and surface modification, especially coating deposition, have been used. Up to now, a large body of in vitro and in vivo studies using $\mathrm{Mg}$ and its alloys have been conducted, and their results revealed the feasibility of $\mathrm{Mg}$ as a promising candidate for bone implants. However, further investigations, including clinical studies, are needed to support the future biomedical application of Mg-based biomaterials as bone implants.

\section{Acknowledgments}

The authors acknowledge the financial support provided by the UEFISCDI through project 65PCCDI/2018, Advanced innovative approaches for predictable regenerative medicine, acronym REGMED.

C) The Author(s) 2020

Open Access This article is distributed under the terms of the Creative Commons Attribution 4.0 International License (http://creativecommons.org/licenses/by/4.0/) which permits unrestricted use, distribution, and reproduction in any medium, provided you give appropriate credit to the original author(s) and the source, provide a link to the Creative Commons license, and indicate if changes were made.

\section{References}

Abdal-Hay A., Amna T., Lim J.K. 2013b. Biocorrosion and osteoconductivity of PCL/nHAp composite porous film-based coating of magnesium alloy. Solid State Sci. 18, 131-140.

Abdal-Hay A., Barakat N.A.M., Lim J.K. 2013a. Hydroxyapatite-doped poly(lactic acid) porous film coating for enhanced bioactivity and corrosion behaviour for AZ31 Mg alloy for orthopedic applications. Ceram. Int. 39, 183-195.

Agarwal S., Curtin J., Duffy B., Jaiswal S. 2016. Biodegradable magnesium alloys for orthopaedic applications: A review on corrosion, biocompatibility and surface modifications. Mater. Sci. Eng. C 68, 948963.

Ahamed M. 2011. Toxic Response of Nickel Nanoparticles in Human Lung Epithelial A549 Cells. Toxicol. In Vitro 25, 930-936.

Antoniac I., Minculescu F., Cotrut C., Ficai A., Rau J.V., Grosu E., Antoniac A., Tecu C., Cristescu I. 2020. Controlling the Degradation Rate of Biodegradabale Mg-Zn-Mn Alloys for Orthopedic Applications by Electrophoretic Deposition of Hydroxyapatite Coating. Materials 13, 263, doi: 10.3390/ma13020263.

Aina V., Malavasi G., Fiorio Pla A., Munaron L., Morterra C. 2009. Zinc-containing bioactive glasses: 
Surface activity and behaviour towards endothelial cells. Acta Biomater. 5, 1211-1222.

Alabbasi A., Liyanaarachchi S., Kannan B.M. 2012. Poly lactic acid coating on a biodegradable magnesium alloy: An in vitro degradation study by electrochemical impedance spectroscopy. Thin Solid Films 520, 6841-6844.

Alvarez-Lopez M., Pereda M.D., Del Valle J., Fernandez-Lorenzo M., Garcia-Alonso M., Ruano O. 2010. Corrosion behaviour of AZ31 magnesium alloy with different grain sizes in simulated biological fluids. Acta Biomater. 6, 1763-1771.

Amini A.R., Wallace J.S., Nukavarapur S.P. 2011. ShortTerm and Long-Term Effects of Orthopedic Biodegradable Implants. J. Long Term. Eff. Med. Implants. 21, 93-122.

Antoniac I., Laptoiu D. 2010. Magnesium alloys-current orthopaedic applications. ASORIS 4, 1-10.

Babkin V.M. 2004. Effect of zirconium on the grain size of magnesium containing $4.5 \% \mathrm{Zn}$. Met. Sci. Heat Treat. 5, 543-544.

Bakhsheshi-Rad H.R., Hamzah E., Ismail A.F., KasiriAsgarani M., Daroonparvar M., Parham S., Iqbal N., Medraj M. 2016. Novel bi-layer nanostructured $\mathrm{SiO}_{2} / \mathrm{Ag}$-FHAp coating on biodegradable magnesium alloy for biomedical applications. Ceram. Int. 42, 11941-111950.

Balamurugan A., Balossier G., Laurent-Maquin D., Pina S., Rebelo A.H.S., Faure J., Ferreira J.M.F. 2008. An in vitro biological and anti-bacterial study on a sol-gel derived silver-incorporated bioglass system. Dent. Mater. 24, 1343-1351.

Bamberger M., Dehm G. 2008. Trends in the development of new Mg alloys. Annu. Rev. Mater. Res. 38, 505-33.

Banks W.A., Kastin A.J. 1989. Aluminum-induced neurotoxicity: alterations in membrane function at the blood-brain barrier. Neurosci. Biobehav. Rev. 13, 4745.

Barlis P., Tanigawa J., Di Mario C. 2007. Coronary bioabsorbable magnesium stent: 15-month intravascular ultrasound and optical coherence tomography findings. Eur. Heart J. 28, 2319, doi: 10.1093/eurheartj/ehm119.

Bch F.W., Schaper M., Jaschik C. 2003. Influence of lithium on hep Mg alloys. Mater. Sci. Forum 1037, 419-422.

Bellantone M., Williams H.D., Hench L.L. 2007. Broadspectrum bactericidal activity of $\mathrm{Ag}_{2} \mathrm{O}$-doped bioactive glass. Antimicrob. Agents Chemother. 46, 1940-1945.

Berglund I.S., Jacobs B.Y., Allen K.D., Kim S.E., Pozzi A., Allen J.B., Manuel M.V. 2016. Peri-implant tissue response and biodegradation performance of a $\mathrm{Mg}$ $1 \mathrm{Ca}-0.5 \mathrm{Sr}$ alloy in rat tibia. Mater. Sci. Eng. C 62, 7985.

Bian D., Deng J., Li N., Chu X., Li W., Cai H., Xiu P., Zhnag Y., Guan Z., Zheng Y., Kou Y., Jiang B., Chen
R. 2018. In vitro and in vivo studies on Biomedical Magnesium Low-Alloying with Elements Gadolinium and Zinc for Orthopedic Implant Applications. ACS. Appl. Mater. Interfaces 10, 4394-4408.

Biesiekierski A., Wang J., Gepreel M. A.-H., Wen C. 2012. A new look at the biomedical Ti-based shape memory alloys. Acta Biomater. 8, 1661-1669.

Birbilis N., Eston M.A., Sudholz A.D., Zhu S.M., Gibson M.A. 2009. On the corrosion of binary magnesiumrare earth alloys. Corros. Sci. 51, 683-689.

Bita A.I., Antoniac I., Ciuca I. 2016. Potential use of Mg$\mathrm{Ca}$ alloys for orthopedics applications. U.P.B. Sci. Bull. 78B, 173-184.

Bita A.I., Antoniac I., Cotrut C. 2016. In Vitro Degradation and Corrosion Evaluation of $\mathrm{Mg}-\mathrm{Ca}$ Alloys for Biomedical Applications. J. Optoelectron. Adv. Mater. 18, 394-398.

Bita A.I., Stan G.E., Minculescu M., Ciuca I., Vasile E., Antoniac I. 2016. Adhesion evaluation of different bioceramics coatings on $\mathrm{Mg}$-Ca alloys for biomedical applications. J. Adhes. Sci. Technol. 30, 1968-1985.

Blaker J.J., Nazhat S.N., Boccaccini A.R. 2004. Development and characterization of silver-doped bioactive glass-coated sutures for tissue engineering and wound healing applications. Biomaterials 25, 1319-1329.

Bobe K., Willbold E., Moegenthal I., Andersen O., Studnitzky T., Nellesen J., Tillmann W., Vogt C., Vano K., Witte F. 2013. In vitro and in vivo evaluation of biodegradable, open-porous scaffolds made of sintered magnesium W4 short fibres. Acta Biomater. 9, 8611-8623.

Boehlert C.J., Knittel K. 2006. The microstructure, tensile properties and creep behaviour of $\mathrm{Mg}-\mathrm{Zn}$ alloys containing 0-4.4.wt \%Zn. Mat. Sci. Eng. A 417, 315-321.

Bornapour M., Muja N., Shum-Tim P., Cerruti M., Pekguleryuz M. 2013. Biocompatibility and biodegradability of $\mathrm{Mg}-\mathrm{Sr}$ alloys: the formation of $\mathrm{Sr}$ substituted hydroxyapatite. Acta Biomater. 9, 53195330.

Borovansky J., Riley P. 1989. Cytotoxicity of zinc in vitro. Chem. Biol. Interact. 69, 279-291.

Bothwell D.N., Mair E.A., Cable B.B. 2003. Chronic Ingestion of a Zinc-Based Penny. Pediatrics 111, 689691.

Bowen P.K., Shearier E.R., Zhao S., Guillory R.J., Zhao F., Goldman J., Drelich J.W. 2016. Biodegradable Metals for Cardiovascular Stents: from Clinical Concerns to recent Zn-Alloys. Adv. Healthc. Mater. 5, 1121-1140.

Brammer K.S., Frandsen C.J., Jin S. 2012. $\mathrm{TiO}_{2}$ nanotubes for bone regeneration. Trends Biotechnol. 30, 315-322.

Brandt E.G., Hellgren M., Brinck T., Bergman T., Edholm O. 2009. Molecular dynamics study of zinc binding to cysteines in a peptide mimic of the alcohol 
dehydrogenase structural zinc site. Phys. Chem. Chem. Phys. 11, 975-983.

Brar H.S., Platt M.O., Sarntinoranont M., Maertin P.I., Manuel M.V. 2009. Magnesium as a biodegradable and bioabsorbable material for medical implants. JOM. 61, 31-34.

Cai S., Lei T., Li N., Feng F. 2012. Effects of Zn on microstructure, mechanical properties and corrosion behaviour of Mg- Zn alloys. Mater. Sci. Eng. C 32, 2570-2577.

Cai S., Xu G., Yu X., Zhang W., Xiao Z., Yao K. 2009. Fabrication and biological characteristics of betatricalciumphosphate porous ceramic scaffolds reinforced with calcium phosphate glass. J. Mater. Sci. Mater. Med. 20, 351-358.

Campos C.M., Muramatsu T., Iqbal J., Zhang Y.J., Onuma Y., Gracia-Garcia H.M., Haude M., Lemos P.A., Warnack B., Serruys P.W. 2013. Bioresorbable Drug-Eluting Magnesium-Alloy Scaffold for Treatment of Coronary Artery Disease. Int. J. Mol. Sci. 14, 24492-24500.

Cannillo V., Sola A. 2009. Potassium-based composition for a bioactive glass. Ceram. Int. 35, 3389-3393.

Castellani C., Lindter R.A., Hausbrandt P., Tschegg E., Stanzl-Tschegg S.E., Zanoni G., Beck S., Weinberg A.-M. 2011. Bone-implant interface strength and osseointegration: Biodegradable magnesium alloy versus standard titanium control. Acta Biomater. 7, 432-440.

Cha P.R., Han H.S., Yang G.F., Kim Y.C., Hong K.H., Lee S.C., Jung J.Y., Ahn J.P., Kim Y.Y., Cho S.Y., Yang S.J., Seok H.K.. 2013. Biodegradability engineering of biodegradable $\mathrm{Mg}$ alloys: Tailoring the electrochemical properties and microstructure of constituent phases. Sci. Rep. 3, 2367, doi: 10.1038/srep02367.

Chappard D., Guillaume B., Mallet R., Pascaretti-Grizon F., Basle M.F., Libouban H. 2010. Sinus lift augmentation and beta-TCP: A micro CT and histologic analysis on human bone biopsies. Micron. 41, 321-326.

Chaya A., Yoshizawa S., Verdelis K., Myers N., Costello B.J., Chou D.T., Pal S., Maiti S., Kumta P.N., Sfeir C. 2015. In vivo study of magnesium plate and screw degradation and bone fracture healing. Acta Biomater. $18,262-269$.

Chen D., He Y., Tao H., Zhang Y., Jiang Y., Zhang X., Zhang S. 2011. Biocompatibility of magnesium-zinc alloy in biodegradable orthopedic implants. Int. J. Mol. Med. 28, 343-348.

Chen K., Xie X., Tang H., Sun H., Qin L., Zheng Y., Gu X., Fan Y. 2020. In vitro and in vivo degradation behaviour of $\mathrm{Mg}-2 \mathrm{Sr}-\mathrm{Ca}$ and $\mathrm{Mg}-2 \mathrm{Sr}-\mathrm{Zn}$ alloys. Bioact. Mater. 5, 275-285.

Chen Y., Xu Z., Smith C., Sankar J. 2014. Recent advances on the development of magnesium alloys for biodegradable implants. Acta Biomater. 10, 15611573.

Chen Y.J., Li Y.J., Walmsley J.C., Dumoulin S., Skaret P.C., Roven H.J. 2010. Microstructure evolution of commercial pure titanium during equal channel angular pressing. Mater. Sci. Eng. A 527, 789-796.

Chen Z., Mao X., Tan L., Friis T., Wu C., Crawford R., Xiao Y. 2014. Osteoimmunomodulatory properties of magnesium scaffolds coated with $\beta$-tricalcium phosphate. Biomaterials 35, 8553-8565.

Chen Z., Wu C., Gu W., Klein T., Crawford R., Xiao Y. 2014. Osteogenic differentiation of bone marrow MSCs by $\beta$-tricalcium phosphate stimulating macrophages via BMP2 signalling pathway. Biomaterials 35, 1507-1518.

Chou D.-T., Hong D., Oksuz S., Schweizer R., Roy A., Lee B., Shridhar P., Gorantla V., Kumta P.N. 2019. Corrosion and bone healing of Mg-Y-Zn-Zr-Ca alloy implants: Comparative in vivo study in a nonimmobilized rat femoral fracture model. J. Biomater. Appl. 33, 1178-1194.

Chou D-T., Hong D., Saha P., Ferrero J., Lee B., Tan Z. 2013. In vitro and in vivo corrosion, cytocompatibility and mechanical properties of biodegradable $\mathrm{Mg}-\mathrm{Y}$ $\mathrm{Ca}-\mathrm{Zr}$ alloys as implant materials. Acta Biomater. 9, 8518-8533.

Cipriano A.F., Sallee A., Guan R-G., Zhao Z-Y., Tayoba M., Sanchez J. 2015. Investigation of magnesiumzinc-calcium alloys and bone marrow derived mesenchymal stem cell response in direct culture. Acta Biomater. 12, 298-321.

Cotton F.A., Wilkinson C., Murillo C.A. Bochmann M. 1999. Advanced Inorganic Chemistry (ed.6) New York: Wiley-Interscience.

Crossgrove J., Zheng W. 2004. Manganese toxicity upon over exposure. N.M.R. Biomed. 17, 544-553.

Cui F., Yang J., Jiao Y., Yin Q., Zhang Y., Lee I.S. 2008. Calcium phosphate coating on magnesium alloy for modification of degradation behavior. Front. Mater. Sci. China 2, 143-148.

Dai H.L., Wang X.Y., Han Y.C., Jiang X., Li S.P. 2011. Preparation and Characterization of Porous Calcium Phosphate Bioceramics. J. Mater. Sci. Technol. 27, 431-436.

Darbre P.D. 2006. Metallo estrogens: an emerging class of inorganic xenoestrogens with potential to add to the oestrogenic burden of the human breast. J. Appl. Toxicol. 26, 191-197.

Delben J.R., Pimentel O.M., Coelho M.B., Candelorio P.D., Furini L.N., dos Santos F.A., de Vicente F.S., Delben A. 2009. Synthesis and thermal properties of nanoparticles of bioactive glasses containing silver. $J$. Therm. Anal. Calorim. 97, 433-436.

Desai T.R., Bhaduri S.B., Tas A.C. 2008. A self-setting, monetite $\left(\mathrm{CaHPO}_{4}\right)$ cement for skeletal repair. Ceram. Eng. Sci. Proc. 27, 61-69. 
Dorea H., McLaughlin R., Cantwell H., Read R., Armbrust L., Pool R., Roush J, Boyle C. 2005. Evaluation of healing in feline femoral defects filled with cancellous autograft, cancellous allograft or Bioglass. Vet. Comp. Orthop. Traumatol. 18,157-168.

Dorozhkin S.V. 2014. Calcium orthophosphate coatings on magnesium and its biodegradable alloys. Acta. Biomater. 10, 2919-2934.

Driessen A., Klein C., Groot K. 1982. Preparation and some properties of sintered [beta]-whitlockite. Biomaterials 3, 113-116.

Drynda A., Hassel T., Hoehn R., Perz A., Bach F., Peuster M. 2010. Development and biocompatibility of a novel corrodible fluoride-coated magnesiumcalcium alloy with improved degradation kinetics and adequate mechanical properties for cardiovascular application. J. Biomed. Mater. Res. 93A, 763-775.

Du H., Wei Z., Wang H., Zhang E., Zuo L., Du L. 2011. Surface microstructure and cell compatibility of calcium silicate and calcium phosphate composite coatings on $\mathrm{Mg}-\mathrm{Zn}-\mathrm{Mn}-\mathrm{Ca}$ alloys for biomedical application. Colloids Surf. B Biointerfaces 83, 96-102.

Du H., Wei Z.J., Liu X.W., Zhang E.L. 2011. Effects of $\mathrm{Zn}$ on the microstructure, mechanical property and bio-corrosion property of $\mathrm{Mg}-3 \mathrm{Ca}$ alloys for biomedical application. Mater. Chem. Phys. 125, 568 575.

Dusková M., Smahel Z., Vohradník M., Tvrdek M., Mazánek J., Kozák J. 2002. Bioactive glass-ceramics in facial skeleton contouring. Aesthetic Plast. Surg. 26, 274-283.

Dziuba D., Meyer-Lindenberg A., Seitz J.M., Waizy H., Angrisani N., Reifenrath J. 2012. Long-term in vivo degradation behavior and biocompatibility of the magnesium alloy ZEK100 for use as a biodegradable bone implant. Acta Biomater. 9, 8548-8560.

Erbe E., Marx J., Clineff T., Bellincampi L. 2001. Potential of an ultraporous $\beta$-tricalcium phosphate synthetic cancellous bone void filler and bone marrow aspirate composite graft. Eur. Spine J. 10, 141-146.

Erbel R., Di Mario C., Bartunek J., Bonnier J., De Bruyne B., Eberli F.R. 2007. Temporary scaffolding of coronary arteries with bioabsorbable magnesium stents: A prospective, non-randomised multicentre trials. Lancet. 369, 1869-1875.

Erdmann N., Bondarenko A., Hewicker-Trautwein M., Angrisani N., Reifenrath J., Lucas A. 2010. Evaluation of the soft tissue biocompatibility of $\mathrm{MgCa} 0.8$ and surgical steel 316L in vivo: A comparative study in rabbits. Biomed. Eng. Online 9, 63, doi: 10.1186/1475-925X-9-63.

Farraro K.F., Kim K.E., Woo S. L-Y., Flowers J.R., McCullough M.B. 2014. Revolutionizing orthopedic biomaterials: the potential of biodegradable and bioresorbable magnesium-based materials for functional tissue engineering. J. Biomech. 47, 19791986.
Fell J., Meadows N., Khan K., Long S., Milla P., Reynolds A. 1996. Manganese toxicity in children receiving long-term parenteral nutrition. Lancet. 347, $1218-1221$.

Feyerabend F., Fischer J., Holtz J., Witte F., Willumeit R., Drucker H. 2010. Evaluation of short-term effects of rare earth and other elements used in magnesium alloys. Acta Biomater. 6, 1834-42.

Fischer J., Profrock D., Hort N., Willumeit R., Feyerabend F. 2013. Improved cytotoxicity testing of magnesium materials. Mater. Sci. Eng. 176, 17731777.

Flaten T. 1990. Geographical associations between aluminium in drinking water and death rates with dementia (including Alzheimer's disease), Parkinson's disease and amyotrophic lateral sclerosis in Norway. Envrion. Geochem. Health 12, 152-167.

Flaten T. 2001. Aluminium as a risk factor in Alzheimer's disease, with emphasis on drinking water. Brain Res. Bull. 55, 187-196.

Gaur S., Singh Raman R.K., Khanna A.S. 2014. In vitro investigation of biodegradable polymeric coating for corrosion resistance of $\mathrm{Mg}-6 \mathrm{Zn}-\mathrm{Ca}$ alloy in simulated body fluid. Mater. Sci. Eng. C 42, 91-101.

Geng F., Tan L.L., Jin X.X., Yang J.Y., Yang K. 2009. The preparation, cytocompatibility, and in vitro biodegradation study of pure beta-TCP on magnesium. J. Mater. Sci. Mater. Med. 20, 11491157.

Ghosh S.K., Nandi S.K., Kundu B., Datta S., De D.K., Roy S.K., Basu D. 2008. In vivo response of porous hydroxyapatite and beta-tricalcium phosphate prepared by aqueous solution combustion method and comparison with bioglass scaffolds. J. Biomed. Mater. Res. 86B, 217-227.

Gray J.E., Luan B. 2002. Protective coatings on magnesium and its alloys-A critical review. J. Alloys Compd. 336, 88-113.

Gray-Munro J.E., Seguin C., Strong M. 2009. Influence of surface modification on the in vitro corrosion rate of magnesium alloy AZ31. J. Biomed. Mater. Res. 91A, 221-230.

Gross U., Strunz V. 2004. The ultrastructure of interface between a glass ceramic and bone. J. Biomed. Mater. Res. 19, 251-271.

Grun N.G., Holweg P., Tangl S., Eichler J., Berger L., van den Beucken J.J.J.P., Loffler J.F., Klestil T., Weinberg A.M. 2018. Comparison of a resorbable magnesium implant in small and large growinganimal models. Acta Biomater. 78, 378-387.

Gu X., Wang F., Xie X., Zheng M., Li P., Zheng Y., Fan Y. 2018. In vitro and in vivo studies on as-extruded Mg-5.25wt\%Zn-0.6wt\%Ca alloy as biodegradable metal. Sci. China Mater. 61, 619-628.

Gu X., Zheng Y.F., Cheng Y., Zhong S., Xi T. 2009. In vitro corrosion and biocompatibility of binary magnesium alloys. Biomaterials 30, 484-498. 
Gu X.N., Xie X.H., Li N., Zheng Y.F., Qin L. 2012. In vitro and in vivo studies on a $\mathrm{Mg}$-Sr binary alloy system developed as a new kind of biodegradable metal. Acta Biomater. 8, 2360-2374.

$\mathrm{Gu}$ X.N., Zheng Y.F. 2010. A review on magnesium alloy as biodegradable materials. Front. Mater. Sci. China 4, 111-115.

Gu X.N., Zheng Y.F., Lan Q.X., Cheng Y., Zhang Z.X., Xi T.F., Zhang D.Y. 2009. Surface modification of an $\mathrm{Mg}-1 \mathrm{Ca}$ alloy to slow down its biocorrosion by chitosan. Biomed. Mater. 4, 044109, doi: 10.1088/1748-6041/4/4/044109.

Haimi S., Gorianc G., Moimas L., Lindroos B., Huhtala H., Räty S., Kuokkanen H., Sándor G.K., Schmid C., Miettinen S., Suuronen R. 2009. Characterization of zinc-releasing three-dimensional bioactive glass scaffolds and their effect on human adipose stem cell proliferation and osteogenic differentiation. Acta Biomater. 5, 3122-3131.

Han J., Wan P., Sun Y., Liu Z., Fan X., Tan L., Yang K. 2016. Fabrication and Evaluation of a Bioactive $\mathrm{Sr}$ Ca-P Contained Micro-Arc Oxidation Coating on Magnesium Strontium Alloy for Bone Repair Application. J. Mater. Sci. Technol. 32, 233-244.

Han P., Cheng P., Zhang S., Zhao C., Ni J., Zhang Y., Zhong W., Hou P., Zhang X., Zheng Y., Chai Y. 2015. In vitro and in vivo studies on the degradation of high-purity $\mathrm{Mg}$ (99.99 wt.\%) screw with femoral intracondylar fractured rabbit model. Biomaterials 64 , 57-69.

Han P., Tan M., Zhang S., Ji W., Li J., Zhang X., Zhao C., Zheng Y., Chai Y. 2014. Shape and site dependent in vivo degradation of $\mathrm{Mg}-\mathrm{Zn}$ pins in rabbit femoral condyle. Int. J. Mol. Sci. 15, 2959-2970.

Hanas T., Kumar T.S.S., Perumal G., Doble M., Ramakrishna S. 2018. Electrospun PCL/HA coated friction stir processed AZ31/HA composites for degradable implant applications. J. Mater. Process Technol. 252, 398-406.

Harandi S.E., Mirshahi M., Koleini S., Idris M.H., Jafari H., Kadir M.R.A. 2013. Effect of calcium content on the microstructure, hardness and in-vitro corrosion behavior of biodegradable $\mathrm{Mg}$-Ca binary alloy. Mater. Res. 16, 11-18.

Hartwig A. 2001. Role of magnesium in genomic stability. Mutat. Res. 475, 113-121.

Haynes W.M. 2013. CRC handbook of chemistry and physics (94th ed), Boca Raton, FL: CRCPress.

Heise S., Wirth T., Hohlinger M., Hernandez Y.T., Ortiz J.A.R., Wagner V., Virtanen S., Boccaccini A.R. 2018. Electrophoretic deposition of chitosan/bioactive glass/silica coatings on stainless steel and WE43 Mg alloy substrates. Surf. Coat. Technol. 344, 553-563.

Hench L.L., Splinter R.J., Allen W.C., Greenlee T.K. 1971, Bonding mechanisms at the interface of ceramic prosthetic materials. J. Biomed. Mater. Res. 5. 117141.
Hench L.L. 1991. Bioceramics: from concept to clinic. $J$. Am. Ceram. Soc. 74, 1487-1510.

Hench L.L. 1998. Bioceramics. J. Am. Ceram. Soc. 81, 1705-1728.

Hench L.L. 2006. The story of Bioglass ${ }^{\circledR}$. J. Mater. Sci. Mater. Med. 17, 967-978.

Heublein B. 2003. Biocorrosion of magnesium alloys: A new principle in cardiovascular implant technology? Heart 89, 651-656.

Hing K.A., Wilson L.F., Buckland T. 2007. Comparative performance of three ceramic bone graft substitutes. Spine J. 7, 475-490.

Hiromoto S., Inoue M., Taguchi T., Yamane M., Ohtsu N. 2015. In vitro and in vivo biocompatibility and corrosion behavior of a bioabsorbable magnesium alloy coated with octacalcium phosphate and hydroxyapatite. Acta Biomater. 11, 520-530.

His C.S., Cheng H.Z., Hsu H.J., Chen Y.S., Wang M.C. 2007. Crystallization kinetics and magnetic properties of iron oxide contained 25Li2O-8MnO2-20CaO2P2O5-45SiO2 glasses. J. Eur. Ceram. Soc. 27, 31713176.

Homayun B., Afshar A. 2014. Microstructure, mechanical properties, corrosion behaviour and cytotoxicity of $\mathrm{Mg}-\mathrm{Zn}-\mathrm{Al}-\mathrm{Ca}$ alloys as biodegradable materials. J. Alloys Compd. 607, 1-10.

Hornberger H., Virtanen S., Boccaccini A. 2012. Biomedical coatings on magnesium alloys: A review. Acta Biomater. 8, 2442-2455.

Hort N., Huang Y., Fechner D., Stormer M., Blawert C., Witte F. 2010. Magnesium alloys as implant materials-principles of property design for $\mathrm{Mg}-\mathrm{RE}$ alloys. Acta Biomater. 6, 1714-1725.

Hsu C., Nazari M.H., Li Q., Shi X. 2019. Enhancing degradation and corrosion resistance of AZ31 magnesium alloy through hydrophobic coating. Mater. Chem. Pshy. 225, 426-432.

Hu G., Zheng L., Du H., Fu X., Jin X., Deng M., Zhao Y., Liu X. 2017. The formation mechanism and biocorrosion properties of $\mathrm{Ag} / \mathrm{HA}$ composite conversion coating on the extruded $\mathrm{Mg}-2 \mathrm{Zn}-1 \mathrm{Mn}-0.5 \mathrm{Ca}$ alloy for bone implant application. Surf. Coat. Technol. 325,127-135.

Huan Z.G., Leeflang M.A., Zhou J., Fratila-Apachitei L.E., Duszczyk J. 2010. In vitro degradation behaviour and cytocompatibility of $\mathrm{Mg}-\mathrm{Zn}-\mathrm{Zr}$ alloys. J. Mater. Sci. Mater. Med. 21, 2623-2635.

Ibrahim H., Esfahani S.N., Poorganji B., Dean D., Elahinia M. 2017. Resorbable bone fixation alloys, forming, and post-fabrication treatments. Mater. Sci. Eng. C 70, 870-888.

Jacobs J.J., Hallab N.J., Skipor A.K., Urban R.M. 2003. Metal degradation products: a cause for concern in metal-metal bearings. Clin. Orthop. Relat. Res. 417, 139-147.

Jahn K., Sait H., Taipaleenmaki H., Gasser S., Hort N., Feyerabend F., Schluter H., Rueger J.M., Lehmann 
W., Willumeit-Romer R., Hesse E. 2016. Intramedullary $\mathrm{Mg} 2 \mathrm{Ag}$ nails augment callus formation during fracture healing in mice. Acta Biomater. 36, 350-360.

Johnson I., Akari K., Liu H. 2013. Nanostructured hydroxyapatite/poly(lactic-co-glycolic acid) composite coating for controlling magnesium degradation in simulated body fluid. Nanotechnology 24, 375103, doi: 10.1088/0957-4484/24/37/375103.

Jones J.R. 2007. Bioactive ceramics and glasses. In: Tissue Engineering Using Ceramics and Polymers, Boccaccini A.R., Gough J.E. (Ed.), UK, Woodhead Publishing Limited, 52-71.

Kaabi Falahieh Asl S., Nemeth S., Tan M.J. 2014. Electrophoretic deposition of hydroxyapatite coating on AZ31 magnesium substrate for biodegradable implant applications. Prog. Cryst. Growth Ch. 60, 7479.

Kaesel V.T., Bach P.T., Haferkamp H., Witte F., Windhagen H. 2004. Approach to control the corrosion of magnesium by alloying. In: Magnesium: Proceedings of the sixth International conference magnesium and their applications, Kainer K.U. (Ed.), New York, Wiley-Vch, 534-539.

Kamrani S., Fleck C. 2019. Biodegradable magnesium alloys as temporary orthopaedic implants: a review. Biometals 32, 185-193.

Kannan M.B., Raman R.K.S. 2008. In vitro degradation and mechanical integrity of calcium-containing magnesium alloys in modified-simulated body fluid. Biomaterials 29, 2306-2314.

Kim J., Mousa H.M., Park C.H., Kim C.S. 2016. Enhanced corrosion resistance and biocompatibility of AZ31 Mg alloy using PCL/ZnO NPs via electrospinning. Appl. Surf. Sci. 396, 249-258.

Kim S-M., Jo J-H., Lee S-M., Kang M-H., Kim H-E., Estrin Y., Lee J-H., Lee J-W., Koh Y-H. 2013. Hydroxyapatite-coated magnesium implants with improved in vitro and in vivo biocorrosion, biocompatibility, and bone response. J. Biomed. Mater. Res. 102A, 429-441.

Kim S-M., Jo J-H., Lee S-M., Kang M-H., Kim H-E., Estrin Y., Lee J-H., Lee J-W., Koh Y-H. 2014. Hydroxyapatite-coated magnesium implants with improved in vitro and in vivo biocorrosion, biocompatibility, and bone response, Wiley Online Library 102, 429-441.

Kim W.C., Kim J.G., Lee J.Y., Seok H.K. 2008. Influence of $\mathrm{Ca}$ on the corrosion properties of magnesium for biomaterials. Mater. Lett. 62, 41464148

Kirkland N.T., Staiger M.P., Nisbet D., Davies C.H.J., Birbilis N. 2011. Performance-driven design of Biocompatible Mg alloys. JOM. 63, 28-34.

Koh J., Choi D. 1994. Zinc toxicity on cultured cortical neurons: Involvement of N-methyl-d-aspartate receptors. Neuroscience 60, 1049-1057.
Kokubo T., Takadama H. 2006. How useful is SBF in predicting in vivo bone bioactivity?. Biomaterials 27 , 2907-2915.

Kraus T., Fischerauer S.F., Hanzi A.C., Uggowitzer P.J., Loffler J.F., Weinberg A.M. 2012. Magnesium alloys for temporary implants in osteosynthesis: in vivo studies of their degradation and interaction with bone. Acta Biomater. 8, 1230-1238.

Krause A., von der Hoh N., Bormann D., Krause C., Back F.-W., Windhagen H., Meyer-Lindenberg A. 2010. Degradation behavior and mechanical properties of magnesium implants in rabbit tibiae. $J$. Mater. Sci. 45, 624-632.

Kulkarni R.K., Pani K.C., Neuman C., Leonard F. 1966. Poly lactic acid for surgical implants. Arch. Surg. 93, 839-843.

Levesque J., Dube D., Fiset M., Mantovani D. 2003. Investigation of corrosion behaviour of magnesium alloy AM60B-F under pseudo-physiological conditions. Mater. Sci. Forum 426, 521-526.

Lhotka C., Szekeres T., Steffan I., Zhuber K., Zweymuller K. 2003. Four-year study of cobalt and chromium blood levels in patients managed with two different metal-on-metal total hip replacement. $J$. Orthop. Res. 21, 189-195.

Li B., Gao P., Zhang H., Guo Z., Zheng Y., Han Y. 2018. Osteoimmunomodulation, osseointegration and in vivo mechanical integrity of HA nanarods/pore-sealed $\mathrm{MgO}$ bilayers coated pure Mg. Biomater. Sci. 6, 32023218.

Li J., Tan L., Wan P., Yu X., Yang K. 2015. Study on microstructure and properties of extruded $\mathrm{Mg}-2 \mathrm{Nd}$ $0.2 \mathrm{Zn}$ alloy as potential biodegradable implant material. Mater. Sci. Eng. B 49, 422-429.

Li J.N., Cao P., Zhang X.N., Zhang S.X., He Y.H. 2010. In vitro degradation and cell attachment of a PLGA coated biodegradable Mg-6Zn based alloy. J. Mater. Sci. 45, 6038-6045.

Li L., Zhang M., Li Y., Zhao J., Qin L., Lai Y. 2017. Corrosion and biocompatibility improvement of magnesium-based alloys as bone implant materials: a review. Regen. Biomater. 4, 129-137.

Li L-H., Sankara Narayanan T.S.N., Kim Y.K., Kong YM., Park I.S., Bae T.S. 2014. Deposition of microarc oxidation-poly caprolactone duplex coating to improve the corrosion resistance of magnesium for biodegradable implants. Thin Solid Films 562, 561567.

Li N., Zheng Y. 2013. Novel Magnesium Alloys Developed for Biomedical Application: A review. J. Mater. Sci. Technol. 29, 489-502.

Li Y., Wen C., Mushahary D., Sravanthi R., Harishankar N., Pande G. 2012. Mg-Zr-Sr alloys as biodegradable implant materials. Acta Biomater. 8, 3177-3188.

Li Z., Gu X., Lou S., Zheng Y. 2008. The development of binary $\mathrm{Mg}-\mathrm{Ca}$ alloys for use as biodegradable materials within bone. Biomaterials 29, 1329-1344. 
Li Z., Shizhao S., Chen M., Fahlman B.D., Debao L., Bi H. 2017. In vitro and in vivo corrosion, mechanical properties and biocompatibility evaluation of $\mathrm{MgF}_{2-}$ coated $\mathrm{Mg}-\mathrm{Zn}-\mathrm{Zr}$ alloy as cancellous screws. Mater. Sci. Eng. C, 1268-1280.

Liao Y., Chen D.S., Niu J.L., Zhang J., Wang Y.P., Zhu Z.J. 2013. In vitro degradation and mechanical properties of polyporous Ca-HPO4-coated $\mathrm{Mg}-\mathrm{Nd}$ $\mathrm{Zn}-\mathrm{Zr}$ alloy as potential tissue engineering scaffold. Mater. Lett. 100, 306-308.

Lin B., Zhong M., Zheng C., Cao L., Wang D., Wang L., Liang J., Cao B. 2015. Preparation and characterization of dopamine-induced biomimetic hydroxyapatite coatings on the AZ31 magnesium alloy. Surf. Coat. Technol. 281, 82-88.

Lin Y., Liu J., Bian D., Huang Z., Lin Z., Wang M., Chu X., Li M., Zhang Y., Zheng Y. 2020. In vivo studies on Mg-1SC alloy for orthopedic applications: a 5months evaluation in rabbits. Mater. Lett. 262, 127130, doi: org/10.1016/j.matlet.2019.127130.

Liu C., Fu X., Pan H., Wen P., Wang L., Tan L., Wang K., Zhao Y., Yang K., Chu P.K. 2016. Biodegradable $\mathrm{Mg}-\mathrm{Cu}$ alloys with enhanced osteogenesis, angiogenesis, and long-lasting antibacterial effects. Sci Rep. 6, 27374, doi: 10.1038/srep27374.

Liu C., Ren Z., Xu Y., Pang S., Zhao X., Zhao Y. 2018. Biodegradable Magnesium Alloys Developed as Bone Repair Materials: A Review. Scanning 15, 9216314, doi: $10.1155 / 2018 / 9216314$.

Liu C., Wan P., Tan L.L., Wang K., Yang K. 2014. Preclinical investigation of an innovative magnesiumbased bone graft substitute for potential orthopaedic applications. J. Orthop. Transl. 2, 139-148.

Liu C., Wang J., Gao C., Wang Z., Zhou X., Tang M., Yu K., Deng Y. 2020. Enhanced osteoinductivity and corrosion resistance of dopamine/gelatine/rhBMP-2coated- $\beta$-TCP/Mg-Zn orthopedic implants: An in vitro and in vivo study. PLOS ONE 15, e0228247, doi: 10.1371/journal.pone.0228247.

Liu C., Xin Y., Tang G., Chu P. 2007. Influence of heat treatment on degradation behaviour of bio-degradable die-cast AZ63 magnesium alloy in simulated body fluid. Mater. Sci. Eng. 456A, 350-357.

Lu S.K., Yeh H.I., Tian T.Y., Lee W.H. 2007. Degradation of magnesium alloys in biological solutions and reduced phenotypic expression of endothelial cell grown on these alloys. In: $3 \mathrm{dn}$ Kuala Lumpur international conference on biomedical engineering, Ibrahim F., Osman N., Usman J., Kandri N. (Ed.), Berlin, Spriner, 98-101.

Makar G.L., Kruger J. 1993. Corrosion of magnesium. Int. Mater. Rev. 38, 138-153.

Makkar P., Jin Kang H., Padalhin A.R., Faruq O., Lee B. 2020. In-vitro and in-vivo evaluation of strontium doped calcium phosphate coatings on biodegradable magnesium alloy for bone applications. Appl. Surf. Sci. 510, 145333, doi: 10.1016/j.apsusc.2020.145333.
Makkar P., Sarkar SK., Padalhin A.R., Moon B.G., Lee Y.S., Lee B.T. 2018. In vitro and in vivo assessment of biomedical $\mathrm{Mg}-\mathrm{Ca}$ alloys for bone implant applications. J. Appl. Biomater. Funct. Mater. 16, 126-136.

Mano J., Sousa R., Boesel L., Neves N., Reis R. 2004. Bioinert, biodegradable and injectable polymeric matrix composites for hard tissue replacement: State of the art and recent developments. Compos. Sci. Technol. 64, 789-817.

Mousa H.M., Abdal-hay A., Bartnikowski M., Mohamed I.M.A., Yasin A.S., Ivanovski S., Park C.H., Kim C.S. 2018. A multifunctional Zinc Oxide/Poly(Lactic Acid) Nanocomposite Layer Coated on Magnesium Alloys for Controlled Degradation and Antibacterial Function. Biomater. Sci. Eng. 4, 2169-2180.

Mueller W.D., Nascimento M.L., de Mele M.F.L. 2010. Critical discussion of the results from different corrosion studies of $\mathrm{Mg}$ and $\mathrm{Mg}$ alloys for biomaterial applications. Acta Biomater. 6, 1749-5175.

Mushahary D., Sravanti R., Li Y., Kumar M.J., Harishakar N., Hodgson P.D., Wen C., Pande G. 2013. Zirconium, calcium and strontium contents in magnesium based biodegradable alloys modulate the efficiency of implant- induced ossoeintegration. Int. J. Nanomed. 8, 2887-2902.

Nair L.S., Laurencin C.T. 2007. Biodegradable polymers as biomaterials. Prog. Polym. Sci. 32, 762-798.

Nakamura Y., Tsumura Y., Tonogai Y., Shibata T., Ito Y. 1997. Differences in behaviour among the chlorides of seven rare earth elements administered intravenously to rats. Fundam. Appl. Toxicol. 37, 106-116.

Nandi S.K., Ghosh S.K., Kundu B., De D.K., Basu D. 2008. Evaluation of new porous beta-tri-calcium phosphate ceramic as bone substitute in goat model. Small Ruminant Res. 75, 144-153.

Neacscu P., Ion R.N., Mitran V., Staras A.I., Campean A. 2015. Stat of the Art and Recent Patents on Mg-Based Biodegradable Bone Implants. Recent Pat. Regen. Med. 4, 168-188.

Neacsu P., Staras A.I., Voicu S.I., Ionascu I., Soare T., Uzun S., Cojocaru V.D., Pandele A.M., Croitoru S.M., Minulescu F., Cotrut C.M., Dan I., Cimpean A. 2017. Characterization and In Vitro and In Vivo Assessment of a Novel Cellulose Acetate-Coated MgBased Alloy for Orthopedic Applications. Materials 10, 686, doi: 10.3390/ma10070686.

Niu J.X., Chen Q.R., Xu N.X., Wei Z.L. 2008. Effect of combinative addition of strontium and rare earth elements on corrosion resistance of AZ91D magnesium alloy. Trans. Nonferrous. Met. Soc. China 18, 1058-1064.

Noshi T., Yoshikawa T., Ikeuchi M., Dohi Y., Ohgushi H., Horiuchi K., Sugimura M., Ichijima K., Yonemasu K. 2000. Enhancement of the in vivo osteogenic potential of marrow/hydroxyapatite composites by 
bovine bone morphogenetic protein. J. Biomed. Mater. Res. 52, 621-630.

Okuma T. 2001. Magnesium and bone strength. Nutrition 17, 679-860.

Pandele A.M., Neacsu P., Cimpean A., Staras A.I., Minculescu F., Iordache A., Voicu S.I., Thakur V.K., Toader O.D. 2018. Cellulose acetate membranes functionalized with resveratrol by covalent immobilization for improved osseointegration. Appl. Surf. Sci. 438, 2-13.

Peng Q.M., Huang Y.D., Zhou L., Hort N., Kainer K.U. 2010. Preparation and properties of high purity $\mathrm{Mg}-\mathrm{Y}$ biomaterials. Biomaterials 31, 398-403.

Persaud-Sharma D., McGoron A. 2012. Biodegradable Magnesium Alloys: A Review of Material Development and Applications. J. Biomim. Biomater. Tissue Eng. 12, 25-39.

Peeters P., Bosiers M., Verbist J., Deloose K., Heublein B. 2005. Preliminary results after application of absorbable metal stents in patients with critical limb ischemia. J. Endovasc. Ther. 12, 1-5.

Peuster M., Hesse C., Schloo T., Fink C., Beerbaum P., von Schnakenburg C. 2006. Long-term biocompatibility of a corrodible peripheral iron stent in the porcine descending aorta. Biomaterials 27, 4955-4962.

Pietak A., Mahoney P., Dias G.J., Staiger M.P. 2008. Bone-like matrix formation on magnesium and magnesium alloys. J. Mater. Sci. Mater. Med. 19, 407-415.

Piskin E., Bolgen N., Egri S., Isoglu I.A. 2007. Electrospun matrices made of poly(a-hydroxy acids) for medical use. Nanomedicine 2, 441-457.

Pogorielov M., Husak E., Solodivnik A., Zhdanov S. 2017. Magnesium-based biodegradable alloys: Degradation application and alloying elements. Interv. Med. Appl. Sci. 9, 27-38.

Poinern G.E.J., Brundavanam S., Fawcett D. 2012. Biomedical Magnesium Alloys: A review of material properties, surface modifications and potential as a biodegradable orthopaedic implant. Am. J. Biomed. Eng. 2, 218-240.

Polmear I.J. 1999. Grades and alloys. In: AMM Specialty Handbook: Magnesium and Magnesium Alloys, Baker H., Avedesian M.M. (Ed.), ASM International, 12-25.

Puelo D.A., Huh W.W. 1995. Acute toxicity of metals ions in cultures of osteogenic cells derived from bone marrow stromal cell. J. Appl. Biomater. 6, 109-116.

Qiu X., Wan P., Tan L., Fan X.M., Yang K. 2014. Preliminary research on a novel bioactive silicon doped calcium phosphate coating on AZ31 magnesium alloy via electrodeposition. Mater. Sci. Eng. C 36, 65-76.

Qu H., Wei M. 2006. The effect of fluoride contents in fluoridated hydroxyapatite on osteoblast behaviour. Acta Biomater. 2, 113-119.

Rad H.R.B., Idris M.H., Kadir M.R.A., Farahany S. 2012. Microstructure analysis and corrosion behaviour of biodegradable Mg-Ca implant alloy. Mater. Design 33, 88-97.

Rau J.V., Antoniac I., Fosca M., De Bonis A., Blajan A.I., Cotrut C., Graziani V., Curcio M., Cricenti A., Niculescu M., Ortenzi M., Teghil R. 2016. Glassceramic coated $\mathrm{Mg}-\mathrm{Ca}$ alloys for biomedical implant applications. Mater. Sci. Eng. C 64, 362-369.

Rau J.V., Antoniac I., Fillipesc M., Cotrut C., Fosca M., Nistor L.C., Birjega R., Dinescu M. 2018. Hydroxyapatite coatings on $\mathrm{Mg}-\mathrm{Ca}$ alloy prepared by Pulsed Laser Deposition: Properties and corrosion resistance in Simulated Body Fluid. Ceram. Int. 44, 16678-16687.

Razavi M., Fathi M., Savabi O., Boroni M. 2012. A review of degradation properties of $\mathrm{Mg}$ based biodegradable implants. The Research and Reviews in Materials Science and Chemistry 1, 15-58.

Razavi M., Fathi M., Savabi O., Vashaee D., Tayebi L. 2014. In vivo study of nanostructured akermanite/PEO coating on biodegradable magnesium alloy for biomedical applications. J. Biomed. Mater. Res. 103A, 1798-1808.

Razavi M., Fathi M., Savabi O., Razavi S.M., Heidari F., Manshaei M., Vashaee D., Tayebi L. 2014. In vivo study of nanostructured diopside $\left(\mathrm{CaMgSi}_{2} \mathrm{O}_{6}\right)$ coating on magnesium alloy as biodegradable orthopedic implants. Appl. Surf. Sci. 313, 60-66.

Report of Environmental Health Impacts from Exposure to Metals, Simla, India, WHO, 2005.

Rezk A.I., Mousa H.M., Lee J., Park C.H., Kim C.S. 2018. Composite PCL/HA/simvastatin electrospun nanofibers coating on biodegradable $\mathrm{Mg}$ alloy for orthopaedic implant application. J. Coat. Technol. Res. 16, 477-489.

Robinson A.D., Griffith R.W., Shechtman D., Evans R.B., Conzemius M.G. 2010. In vitro antibacterial properties of magnesium metal against Escherichia coli, Pseudomonas aeruginosa and Staphylococcus aureus. Acta Biomater. 6, 1869-1877.

Rojaee R., Fathi M., Raeissi K. 2013. Controlling the degradation rate of AZ91 magnesium alloy via sol-gel derived nanostructured hydroxyapatite coating. Mater. Sci. Eng. C 33, 3817-3825.

Rojaee R., Fathi M., Raeissi K., Taherian M. 2014. Electrophoretic deposition of bioactive glass nanopowders on magnesium based alloy for biomedical applications. Ceram. Int. 40, 7879-7888.

Rokn A., Moslemi N., Eslami B., Abadi H.K., Paknejad M. 2012. Histologic evaluation of bone healing following application of an organic bovine bone and beta-tricalcium phosphate in rabbit calvaria. J. Dent. 9, 35-40.

Rossing C., Angrisani N., Helmecke P., Besdo S., Seitz J.M., Welke B., Fedchenko N., Kock H., Reifenerath J. 2015. In vivo evaluation of a magnesium-based degradable intramedullary nailing system in a sheep model. Acta Biomater. 25, 369-383. 
Roy A., Singh S.S., Datta M.K., Lee B., Ohodnicki J., Kumta P.N. 2011. Novel sol-gel derived calcium phosphate coatings on Mg4Y alloy. Mater. Sci. Eng. 176B, 1679-1689.

Saiz E., Zimmermannb E.A., Lee J.S., Wegstd U.G.K., Tomsia A.P. 2013. Perspectives on the role of nanotechnology in bone tissue engineering. Dent. Mater. 29, 103-115.

Salahshoor M., Guo Y. 2012. Biodegradable orthopedic magnesium calcium ( $\mathrm{MgCa}$ ) alloys, processing, and corrosion performance. Materials 5, 135-155.

Schmidt W., Behrens P., Brandt-Wunderlich C., Siewert S., Grabow N., Schmitz K.P. 2016. In vitro performance investigation of bioresorbable scaffoldsStandard tests for vascular stents and beyond. Cardiovasc. Revasc. Med. 17, 375-383.

Schranz D., Zartner P., Michel-Behnke I., Akinturk H. 2006. Bioabsorbable metal stents for percutaneous treatment of critical recoarctation of the aorta in a new born. Catheter. Cardiovasc. Interv. 67, 671-673.

Seal C.K., Vince K., Hodgson M.A. 2009. Biodegradable Surgical Implants based on Magnesium Alloys - A Review of Current Research. IOP Conf. Series: Materials Scienece and Engineering 4, 012011.

Sedelnikova M.B., Komarova E.G., Sharkeev Y.P., Tolkacheva T.V., Sheikin V.V., Egorkin V.S., Mashtalyar D.V., Kazakbaeva A.A., Schmidt J. 2018. Characterization of Micro-Arc Coatings Containing beta-Tricalcium Phosphate Particles on $\mathrm{Mg}-0.8 \mathrm{Ca}$ Alloys. Metals 8, 238, doi: 10.3390/met8040238.

Seitz J.M., Collier K., Wulf E., Bormann D., Bach F.W. 2011. Comparison of the corrosion behavior of coated and uncoated magnesium alloys in an in vitro corrosion environment. Adv. Eng. Mater. 13, 313323.

Seitz J.M., Lucas A., Kirschner M. 2016. MagnesiumBased Compression Screws: A Novelty in the Clinical Use of Implants. JOM 68, 1177-1182.

Sezer N., Evis Z., Kayhan S.M., Tahmasebifar A., Koc M. 2018. Review of magnesium-based biomaterials and their applications. J. Magnes. Alloys 6, 23-43.

Shadanbaz S., Diaz G. 2012. Calcium phosphate coatings on magnesium alloys for biomedical applications: A review. Acta Biomater. 8, 20-30.

Shin H., Jo S., Mikos A.G. 2003. Biomimetic materials for tissue engineering. Biomaterials 24, 4353-4364.

Shuai C.J., Li S., Peng S.P., Feng P., Lai Y.X., Gao C.D. 2019. Biodegradable metallic bone implants. Mater. Chem. Front. 3, 544-562.

Song G., Atrens. 2003. Understanding magnesium corrosion: A framework for improved alloy performance. Adv. Eng. Mater. 5, 837-858.

Song G.L., Atrens A. 1999. Corrosion mechanisms of magnesium alloys. Adv. Eng. Mater. 1, 11-33.

Song M.-S., Zeng R.-C., Ding Y.-F., Li R.W., Easton M., Cole I., Birbilis N., Chen X.B. 2019. Recent advances in biodegradation controls over $\mathrm{Mg}$ alloys for bone fracture management: A review. J. Mater. Sci. Technol. 35, 535-544.

Staiger M.P., Pietak A.M., Huadmai J., Dias G. 2006. Magnesium and alloys as orthopedic biomaterials: a review. Biomaterials 27, 1728-1734.

Sun W., Zhang G., Tan L., Yang K., Ai H. 2016. The fluoride coated AZ31B magnesium alloy improves corrosion resistance and stimulates bone formation in rabbit model. Mater. Sci. Eng. C 63, 506-511.

Surmenev R.A., Surmeneva M.A., Ivanova A.A. 2014. Significance of calcium phosphate coatings for the enhancement of new bone osteogenesis-A review. Acta Biomater. 10, 557-579.

Takahashi Y., Yamamoto M., Tabata Y. 2007. Enhanced osteoinduction by controlled release of bone morphogenetic protein-2 from biodegradable sponge composed of gelatin and $\beta$-tricalcium phosphate. Biomaterials 26, 4856-4865.

Tan L., Yu X., Wan P., Yang K. 2013. Biodegradable Materials for Bone Repairs: A review. J. Mater. Sci. Technol. 29, 503-513.

Tang Y.C., Katsuma S., Fujimoto S., Hiromoto S. 2006. Electrochemical study of Type 304 and 316L stainless steels in simulated body fluids and cell cultures. Acta Biomater. 2, 709-715.

TenHuisen K., Brown P. 1998. Formation of calciumdeficient hydroxyapatite from [alpha]-tri-calcium phosphate. Biomaterials 19, 2209-2217.

Tian L., Sheng Y., Huang L., Chow D.H., Chau W.H., Tang N., Ngai T., Wu C., Lu J., Qin L. 2018. An innovative $\mathrm{Mg} / \mathrm{Ti}$ hybrid fixation system developed from fracture fixation and healing at load-bearing skeletal site. Biomaterials 181, 173-183.

Tian P., Liu X. 2015. Surface modification of biodegradable magnesium and its alloys for biomedical applications. Regen. Biomater. 1, 135-151.

Tie D., Feyerabend F., Muller W.D., Schade R., Liefeith K., Kainer K.U., Willumeit R. 2013. Antibacterial biodegradable Mg-Ag alloys. Eur. Cell Mater. 25, 284-298.

Vitale-Brovarone C., Miola M., Balagna C., Verné E. 2008. 3D-glass-ceramic scaffolds with antibacterial properties for bone grafting. Chem. Eng. J. 137, 129136.

Vitale-Brovarone C., Verne E., Robiglio L., Appendino P., Bassi F., Martinasso G., Muzio G., Canuto R. 2007. Development of glass-ceramic scaffolds for bone tissue engineering: characterization, proliferation of human osteoblasts and nodule formation. Acta Biomater. 3, 199-208.

Vogel M., Voigt C., Gross U.M., Muller-Mai C.M. 2001. In vivo comparison of bioactive glass particles in rabbit. Biomaterials 22, 357-362.

Vojtech D., Kubasek J., Capek J., Pospisilova I. 2014. Magnesium, Zinc and Iron for Medical Applications in Biodegradable Implants, METAL 2014 - 23rd 
International Conference on Metallurgy and Materials, Conference Proceedings, 1092-1096.

Waksman R., Erbel R., Di Mario C., Bartunek J., De Bruyne B., Ilsley C. 2009. Early- and long-term intravascular ultrasound and angiographic findings after bioabsorbable magnesium stent implantation in human coronary arteries. JACC Cardiovasc. Interv. 2, 312-320.

Waksman R., Pakala R., Kuchulakanti P.K., Baffour R., Hellinga D., Seabron R. 2006. Safety and efficacy of bioabsorbable magnesium alloy stents in porcine coronary arteries. Catheter. Cardiovasc. Interv. 68, 606-617.

Waksman R., Pakala R., Okabe T., Hellinga D., Chan R., Tio M.O. 2007. Efficacy and safety of absorbable metallic stents with adjunct intracoronary beta radiation in porcine coronary arteries. J. Inter. Cardiol. 20, 367-372.

Walker J., Shadanbaz S., Woodfield T.B.F., Staiger M.P., Dias G.J. 2014. Magnesium biomaterials for orthopedic applications: A review from a biological perspective. J. Biomed. Mater. Res. 102B, 1316-1331.

Wancket L.M. 2015. Animal models for evaluation of bone implants and devices: comparative bone structure and common model uses. Vet. Pathol. 52, 842-850.

Wang B., Huang P., Ou C., Li K., Yan B., Lu W. 2013. In vitro Corrosion and Cytocompatibility of ZK60 Magnesium Alloy Coated with Hydroxyapatite by a Simple Chemical Conversion Process for Orthopedic Applications. Int. J. Mol. Sci. 14, 23614-23628.

Wang H., Guan S., Wang Y., Liu H., Wang H., Wang L., Ren C., Zhu S., Chen K. 2011. In vivo degradation behavior of Ca-deficient hydroxyapatite coated $\mathrm{Mg}$ $\mathrm{Zn}-\mathrm{Ca}$ alloy for bone implant application. Colloids Surf. B Biointerfaces 88, 254-259.

Wang H., Shi Z. 2011. In vitro biodegradation behaviour of magnesium and magnesium alloy. J. Biomed. Mater. Res. 98B, 203-209.

Wang J., Cui L., Ren Y., Zou Y., Ma J., Wang C., Zheng Z., Chen X., Zeng R., Zheng Y. 2019. In vitro and in vivo biodegradation and biocompatibility of a MMT/BSA composite coating upon magnesium alloy AZ31. J. Mater. Sci. Technol. 47, 52-67.

Wang J., Tang J., Zhang P., Li Y., Lai Y., Qin L. 2012. Surface modifications of magnesium alloys developed for bioabsorbable orthopedic implants: A general review. J. Biomed. Mater. Res. 100B, 1691-1701.

Wang L.J., Xu J., Fu W., Cheng W., Chan K., Yung P.S., Qin L. 2017. Biodegradable Magnesium Screws Accelerate Fibrous Tissue Mineralization in the TendBone insertion in Anterior Cruciate Ligament Reconstruction Model of Rabbit. Sci. Rep. 7, 40369, doi: 10.1016/j.biomaterials.2020.119962.

Wang Z., Wang X., Tian Y., Pei J., Zhang J., Jiang C., Huang J., Pang Z., Cao Y., Wang X., An S., Wang X., Huang H., Yuan G., Yan Z. 2020. Degradation and osteogenic induction of a $\mathrm{SrHPO}_{4}$-coated $\mathrm{Mg}-\mathrm{Nd}-\mathrm{Zn}$ -
$\mathrm{Zr}$ alloy intramedullary nail in a rat femoral shaft fracture model. Biomaterials 247, 119962, doi: 10.1016/j.biomaterials.2020.119962.

Wen Z.H., Wu C.J., Dai C.S., Yang F.X. 2009. Corrosion behaviors of $\mathrm{Mg}$ and its alloys with different $\mathrm{Al}$ contents in a modified simulated body fluid. J. Alloy Compd. 488, 392-399.

Willbold E., Gu X., Albert D., Kalla K., Bobe K., Brauneis M. 2015. Effect of the addition of low rare earth elements (lanthanum, neodymium, cerium) on the biodegradation and biocompatibility of magnesium. Acta Biomater. 11, 554-562.

Willbold E., Kalla K., Bartsch I., Bobe K., Brauneis M., Remennik S. 2013. Biocompatibility of rapidly solidified magnesium alloy RS66 as a temporary biodegradable metal. Acta Biomater. 9, 8509-8517.

Willbold E., Kaya A.A., Kaya R.A., Beckmann F., Witte F. 2011. Corrosion of magnesium alloy AZ31 screws in dependent on the implantation site. Mater. Sci. Eng. $B$ 176, 1835-1840.

Wills M., Savory J.1983 .Aluminium poisoning: Dialysis, encephalopathy, osteomalacia and anaemia. Lancet. 2, 29-34.

Windhagen H., Radtke K., Weizbauer A., Diekmann J., Noll Y., Kreimeyer U., Schavan R., StukenborgColsman C., Waizy H. 2013. Biodegradable magnesium-based screw clinically equivalent to titanium screw in hallux valgus surgery: short term results of the first prospective, randomized, controlled clinical pilot study. Bio. Med. Eng. Online 12, 62, doi: 10.1186/1475-925X-12-62.

Witte F. 2010. The history of biodegradable magnesium implants: A review. Acta Biomater. 6, 1680-1692.

Witte F., Abeln I., Switzer E., Kaese V., MeyerLindenberg A., Windhagen H. 2007. Evaluation of the skin sensitizing potential of biodegradable magnesium alloys. J. Biomed. Mater. Res. 86A, 1041-1047.

Witte F., Fischer J., Nellesen J., Crostack H.A., Kaese V., Pisch A. 2006. In vitro and in vivo corrosion measurements of magnesium alloys. Biomaterials 27, 1013-1018.

Witte F., Hort N., Vogt C., Cohen S., Kainer K.U., Willumeit R. 2008. Degradable biomaterials based on magnesium corrosion. Curr. Opin. Solid State Mater. Sci. 12, 63-72.

Witte F., Kaese V., Haferkamp H. 2005. In vivo corrosion of four magnesium alloys and the associated bone response. Biomaterials 26, 3557-3563.

Wong H.M., Yeung K.W.K., Lam K.O., Tam V., Chu P.K., Luk K.D.K., Cheung K.M.C. 2010. A biodegradable polymer-based coating to control the performance of magnesium alloy orthopaedic implants. Biomaterials 31, 2084-2096.

Wu S., Liu X., Yeung K.W.K., Guo H., Li P., Hu T., Chung C.Y., Chu P.K. 2013. Surface nanoarchitectures and their effects on the mechanical properties and corrosion behaviour of Ti-based orthopedic implants. Surf. Coat. Technol. 233, 13-26. 
Wua L., Luthringer B.J.C., Feyerabend F., Schilling A.F., Willumeit R. 2014. Effects of extracellular magnesium on the differentiation and function of human osteoclasts. Acta Biomater. 10, 2843-2854.

Xia D., Liu Y., Wang S., Zeng R.-C., Liu Y., Zheng Y., Zhou Y. 2018. In vitro and in vivo investigation on biodegradable $\mathrm{Mg}$-Li-Ca alloys for bone implant application. Sci. China Mater. 62, 256-272.

Xin Y., Hu T., Chu P.K. 2010. In vitro studies of biomedical magnesium alloys in a simulated physiological environment: A review. Acta Biomater. 7, 1452-1459.

Xin Y., Hu T., Chu P.K. 2011. In vitro studies of biomedical magnesium alloys in a simulated physiological environment: A review. Acta Biomater. 7, 1452-1459.

$\mathrm{Xu}$ L., Yamamoto A. 2012. Characteristics and cytocompatibility of biodegradable polymer film on magnesium by spin coating. Colloids Surf. B Biointerfaces 93, 67-74.

Xu L., Yamamoto A. 2012. In vitro degradation of biodegradable polymer-coated magnesium under cell culture condition. Appl. Surf. Sci. 258, 6353-6358.

Xu L., Zhang E., Yang K. 2009. Phosphating treatment and corrosion properties of $\mathrm{Mg}-\mathrm{Mn}-\mathrm{Zn}$ alloy for biomedical application. J. Mater. Sci. Mater. Med. 20, 859-867.

Xu L., Zhang E., Yin D., Zeng S., Yang K. 2008. In vitro corrosion behaviour of $\mathrm{Mg}$ alloys in a phosphate buffered solution for bone implant application. $J$. Mater. Sci. Mater. Med. 19, 1017-1025.

Xu Z.G., Smith C., Chen S.O., Sankar J. 2011. Development and microstructural characterizations of $\mathrm{Mg}-\mathrm{Zn}-\mathrm{Ca}$ alloys for biomedical applications. Mater. Sci. Eng. B 176, 1660-1665.

Yang J., Cui F., Lee I.S. 2011. Surface Modifications of Magnesium Alloys for Biomedical Applications. Ann. Biomed. Eng. 39, 1857-1871.

Yang L., Huang Y.D., Feyerabend F., Willumeit R., Kainer K.U., Hort N. 2012. Influence of ageing treatment on microstructure, mechanical and biocorrosion properties of Mg-Dy alloys. J. Mech. Behav. Biomed. Mater. 13, 36-44.

Yang W.D., Zhang P., Liu J.S., Xue Y.F. 2006. Effect of long-term intake of $\mathrm{Y} 3+$ in drinking water on gene expression in brains of rat. J. Rare Earth 24, 369373.

Yang Z., Li J.P., Zhang J.X., Lorimer G.W., Robson J. 2008. Review on research and development of magnesium alloys. Acta Metall. Sin.-Engl. 21, 313328.

Yanovska A., Kuznetsov V., Stanislavov A., Danilchenko S., Sukhodub L. 2012. Calcium phosphate coatings obtained biomimetically on magnesium substrates under low magnetic field. Appl. Surf. Sci. 258, 8577-8584.
Yin Z.Z., Qi W.C., Zeng R.C., Chen X.B., Gu C.D., Guan S.K., Zheng Y.F. 2020. Advances in coatings on biodegradable magnesium alloys. J. Magnes. Alloys 8, 42-65.

Yu K., Chen L., Zhao J., Li S., Dai Y., Huang Q., Yu Z. 2012. In vitro corrosion behaviour and in vivo biodegradation of biomedical $\beta-\mathrm{Ca}_{3}\left(\mathrm{PO}_{4}\right)_{2} / \mathrm{Mg}-\mathrm{Zn}$ composites. Acta Biomater. 8, 311-314.

Yu K., Dai Y., Luo Z., Long H., Zeng M., Li Z., Zhu J., Cheng L., Zhang Y., Liu H., Zhu Y. 2018. In vitro and in vivo evaluation of novel biodegradable $\mathrm{Mg}-\mathrm{Ag}-\mathrm{y}$ alloys for use as resorbable bone fixation implant. $J$. Biomed. Mater. Res. 106A, 2059-2069.

Yu N., Cai S., Wang F., Zhang F., Ling R., Li Y., Jiang Y., Hu G. 2016. Microwave assisted deposition of strontium doped hydroxyapatite coating on AZ31 magnesium alloy with enhanced mineralization ability and corrosion resistance. Ceram. Int. 43, 2495-2503.

Yubao L., Xingdong Z., De Groot K. 1997. Hydrolysis and phase transition of alpha-tri-calcium phosphate. Biomaterials 18, 737-741.

Yumiko N., Yukari T., Yasuhide T., Tadashi S., Yoshio I. 1997. Differences in behaviour among the chlorides of seven rare earth elements administered intravenously to rats. Fundam. Appl. Toxicol. 37, 106116.

Yun Y.H., Dong Z., Yang D., Schulz M.J., Shanov V.N., Yarmolenko S. 2009. Biodegradable Mg corrosion and osteoblast cell culture studies. Mater. Sci. Eng. C 29, 1814-1821.

Zartner P., Buettner M., Singer H., Sigler M. 2007. First Biodegradable metal stent in a child with congenital heart disease: Evaluation of macro and histopathology. Catheter. Cardiovasc. Interv. 69, 443446.

Zartner P., Cesnjevar R., Singer H., Weyand M. 2005. First success full implantation of a biodegradable metal stent into the left pulmonary artery of a preterm baby. Catheter. Cardiovasc. Interv. 66, 590-594.

Zberg B., Uggowitzer P., Loffler J. 2009. MgZnCa Glasses without Clinically Observable Hydrogen Evolution for Biodegradable Implants. Nat. Mater. 8, 887-891.

Zeng R.C., Cui L., Jiang K., Liu R., Zhao B., Zheng Y. 2016. In Vitro Corrosion and Cytocompatibilty of a Microarc Oxidation Coating and Poly(L-Lactic acid) Composite Coating on $\mathrm{Mg}-1 \mathrm{Li}-1 \mathrm{Ca}$ Alloy for Orthopaedic Implants. ACS Appl. Mater. Interfaces 8, 10014-10028.

Zhang B.P., Wang Y., Geng L. 2001. Research on Mg$\mathrm{Zn}-\mathrm{Ca}$ alloy as degradable biomaterial. In: Biomaterials - Physics and Chemistry, Pignatello R. (Ed.), Zurich, In Tech, 183-204.

Zhang C., Zeng R., Chen R., Liu C., Gao J. 2010. Preparation of calcium phosphate coatings on Mg-1.0 Ca alloy. Trans. Noferrous. Met. Soc. China 20, 655659. 
Zhang E., Xu L., Yu G., Pan F., Yang K. 2009. In Vivo Evaluation of Biodegradable Magnesium Alloy Bone Implant in the First 6 Months Implantation. $J$. Biomed. Mater. Res. 90A, 882-893.

Zhang E., Yin D., Xu L., Yang L., Yang K. 2009. Microstructure, mechanical and corrosion properties and biocompatibility of $\mathrm{Mg}-\mathrm{Zn}-\mathrm{Mn}$ alloys for biomedical application. Mater. Sci. Eng. C 29, $987-$ 993.

Zhang E.L., Yang L., Xu J.W., Chen H.Y. 2010. Microstructure, mechanical properties and biocorrosion properties of $\mathrm{Mg}-\mathrm{Si}(-\mathrm{Ca}, \mathrm{Zn})$ alloy for biomedical application. Acta Biomater. 6, 1756-1762.

Zhang G.D., Huang J.J., Yang K., Zhang B.C., Ai H.J. 2007. Experimental Study of In Vivo Implantation of Magnesium Alloy at Early Stage. Acta Metall. Sin. 43, 1186-1190.

Zhang J., Dai C., Wei J., Wen Z.H., Zhang S., Chen C. 2013. Degradable behaviour and bioactivity of microarc oxidized AZ91D $\mathrm{Mg}$ alloy with calcium phosphate/chitosan composite coating in m-SBF. Colloids Surf. B Biointerfaces 111, 179-187.

Zhang J., Dai C.S., Wei J., Wen Z.H. 2012. Study on the bonding strength between calcium phosphate/chitosan composite coatings and a $\mathrm{Mg}$ alloy substrate. Appl. Surf. Sci. 261, 276-286.

Zhang S., Zhang X., Zhao C., Li J., Song Y., Xie C. 2010. Research on the Mg-Zn alloy as a degradable biomaterial. Acta Biomater. 6, 626-640.

Zhang W., Li M., Chen Q., Hu W., Zhang W., Xin W. 2012. Effects of $\mathrm{Sr}$ and $\mathrm{Sn}$ on microstructure and corrosion resistance of $\mathrm{Mg}-\mathrm{Zr}-\mathrm{Ca}$ magnesium alloy for biomedical applications. Mater. Design 39, 379383.

Zhang X.B., Wu Y.J., Xue Y.J., Wang Z.Z., Yang L. 2012a. Biocorrosion behavior and cytotoxicity of an $\mathrm{Mg}-\mathrm{Gd}-\mathrm{Zn}-\mathrm{Zr}$ alloy with long period stacking ordered structure. Mater. Lett. 86, 42-45.
Zhang X.B., Yuan G.Y., Mao L., Niu J.L., Fu P.H., Ding W.J. 2012b. Effects of extrusion and heat treatment on the mechanical properties and biocorrosion behaviors of an $\mathrm{Mg}-\mathrm{Nd}-\mathrm{Zn}-\mathrm{Zr}$ alloy. J. Mech. Behav. Biomed. Mater. 7, 77-86.

Zhang Y., Xu J., Ruan Y.C., Yu M.K., O'Laughlin M., Wise H., Chen D., Tian L., Shi D., Wang J., Chen S., Feng J.Q., Chow D.H., Xie X., Zheng L., Huang L., Huang S., Leung K., Lu N., Zhao L., Li H., Zhao D., Gou X., Chen K., Witte F., Chan H.C., Zheng Y., Qin L. 2016. Implant-derived Magnesium Induces Local Neuronal Production of CGRP to Improve BoneFracture Healing in Rats. Nat. Med. 22, 1160-1169.

Zhao C., Pan F., Zhang L., Pan H., Song K., Tang A. 2017. Microstructure, mechanical properties, biocorrosion properties and cytotoxicity of as-extruded Mg-Sr alloys. Mater. Sci. Eng. C 70, 1081-1088.

Zhao D., Huang S., Lu F., Wang B., Yang L., Qin L., Yang K., Li Y., Li W., Wang W., Tian S., Zhang X., Gao W., Wang Z., Zhang Y., Xie X., Wang J., Li J. 2016. Vascularized bone grafting fixed by biodegradable magnesium screw for treating osteonecrosis for the femoral head. Biomaterials 81, 84-92.

Zhao D.W., Witte F., Lu F.Q., Wang J.L., Qin L. 2017. Current status on clinical applications of magnesiumbased orthopaedic implants: A review from clinical translation perspective. Biomaterials 112, 287-302.

Zhao Y., Jamesh M.I., Li W.K., Wu G., Wang C., Zheng Y., Yeung K.W.K., Chu P.K. 2014. Enhanced antimicrobial properties, cytocompatibility, and corrosion resistance of plasma-modified biodegradable magnesium alloys. Acta Biomater. 10, 544-556.

Zheng Y.F., Gu X.N., Witte F. 2014. Biodegradable metals. Mater. Sci. Eng. R 77, 1-34.

Zhou P., Gong H.R. 2012. Phase stability, mechanical property, and electronic structure of an $\mathrm{Mg}-\mathrm{Ca}$ system. J. Mech. Behav. Biomed. Mater. 8, 154-164. 